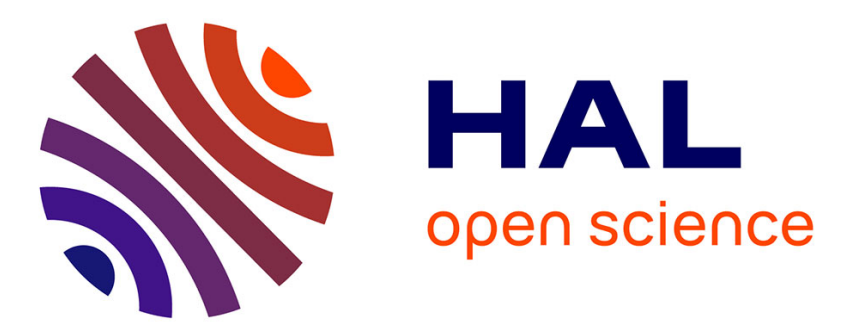

\title{
Experimental and Theoretical Contribution to the Phase Equilibria in the Ternary CaO-Al2O3-B2O3 System
}

\author{
Frédérique Ferey, Vincent Briaud, Perrine Violet, Alexander Pisch
}

\section{To cite this version:}

Frédérique Ferey, Vincent Briaud, Perrine Violet, Alexander Pisch. Experimental and Theoretical Contribution to the Phase Equilibria in the Ternary CaO-Al2O3-B2O3 System. Journal of Phase Equilibria and Diffusion, 2020, 41 (4), pp.443-456. 10.1007/s11669-020-00803-7 . hal-03020738

\section{HAL Id: hal-03020738 https://hal.science/hal-03020738}

Submitted on 24 Nov 2020

HAL is a multi-disciplinary open access archive for the deposit and dissemination of scientific research documents, whether they are published or not. The documents may come from teaching and research institutions in France or abroad, or from public or private research centers.
L'archive ouverte pluridisciplinaire HAL, est destinée au dépôt et à la diffusion de documents scientifiques de niveau recherche, publiés ou non, émanant des établissements d'enseignement et de recherche français ou étrangers, des laboratoires publics ou privés. 


\section{Journal of Phase Equilibria and Diffusion}

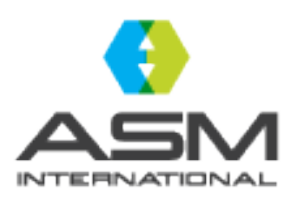

\section{Experimental and theoretical contribution to the phase equilibria in the ternary CaO-Al203-B2O3 system}

\begin{tabular}{|r|l|}
\hline Journal: & Journal of Phase Equilibria and Diffusion \\
\hline Manuscript ID & JPED-20-01-2345.R3 \\
\hline Manuscript Type: & Research Article \\
\hline Author: & nomita \\
\hline Complete List of Authors: & $\begin{array}{l}\text { Ferey, Frédérique; Lafarge Centre de Recherche Saint-Quentin-Fallavier } \\
\text { Briaud, Vincent; Lafarge Centre de Recherche Saint-Quentin-Fallavier } \\
\text { Violet, Perrine; UGA, SIMaP } \\
\text { Pisch, Alexander; UGA/CNRS/INPG, Laboratoire SIMaP; }\end{array}$ \\
\hline Keywords: & $\begin{array}{l}\text { CaO-Al2O3-B2O3, experimental phase Equilibria, thermodynamic } \\
\text { properties, invariant equilibria, DFT }\end{array}$ \\
\hline &
\end{tabular}

\section{SCHOLARONE \\ Manuscripts}


Experimental and theoretical contribution to the phase equilibria in the ternary $\mathrm{CaO}^{-} \mathrm{Al}_{2} \mathrm{O}_{3}$ $\mathrm{B}_{2} \mathbf{O}_{3}$ system

Frédérique FEREY ${ }^{1}$, Vincent BRIAUD ${ }^{1}$, Perrine VIOLET ${ }^{2}$, Alexander PISCH ${ }^{2,}$,

${ }^{1}$ Lafarge Centre de Recherche, 95 Rue du Montmurier-BP15, 38291 Saint Quentin-Fallavier Cedex

${ }^{2}$ Univ. Grenoble Alpes, CNRS, Grenoble INP, SIMaP, F-38000 Grenoble, France

*corresponding author: alexander.pisch@simap.grenoble-inp.fr

To the memory of Günther Effenberg

\begin{abstract}
The phase equilibria in the lime rich part of the $\mathrm{CaO}-\mathrm{Al}_{2} \mathrm{O}_{3}-\mathrm{B}_{2} \mathrm{O}_{3}$ ternary system were investigated by thermodynamic modeling and key experiments. Three ternary compounds, $\mathrm{CaAl}_{2} \mathrm{~B}_{2} \mathrm{O}_{7}(\mathrm{CAB})$, $\mathrm{Ca}_{2} \mathrm{Al}_{2} \mathrm{~B}_{2} \mathrm{O}_{8}\left(\mathrm{C}_{2} \mathrm{AB}\right)$ and $\mathrm{Ca}_{2} \mathrm{Al}_{2} \mathrm{~B}_{6} \mathrm{O}_{14}\left(\mathrm{C}_{2} \mathrm{AB}_{3}\right)$, are reported in the literature and their thermodynamic properties were calculated using Density Functional Theory and lattice dynamics theory. Partial isothermal sections of the lime rich part of the $\mathrm{CaO}-\mathrm{Al}_{2} \mathrm{O}_{3}-\mathrm{B}_{2} \mathrm{O}_{3}$ were investigated at $950^{\circ} \mathrm{C}$ and $1020^{\circ} \mathrm{C}$ using solid state reactions and X-ray diffraction on 14 selected samples. The observed results confirm the available experimental data from the literature. Based on thermal analysis using differential scanning calorimetry, the $\mathrm{Ca}_{3} \mathrm{Al}_{2} \mathrm{O}_{6}-\mathrm{CaB}_{2} \mathrm{O}_{4}$ and $\mathrm{CaAl}_{2} \mathrm{O}_{4}-\mathrm{CaB}_{2} \mathrm{O}_{4} \mathrm{~T}-\mathrm{x}$ sections as well as a tentative partial liquid surface of the lime rich part were constructed.
\end{abstract}

Key words $\mathrm{CaO}-\mathrm{Al}_{2} \mathrm{O}_{3}-\mathrm{B}_{2} \mathrm{O}_{3}$; phase equilibria; thermodynamic properties, invariant reactions; partial liquidus surface 


\section{Introduction}

Small additions of boron oxide to a limestone-bauxite/kaolin-silica-calcium sulfate raw mix lead to a new class of low $\mathrm{CO}_{2}$ hydraulic binders [1,2] now commonly cited as BYF (Belite-Ye'elimiteFerrite) cements in the scientific literature [3]. Boron oxide plays two different roles in the clinker formulation: it stabilizes the high temperature modification of $\mathrm{Ca}_{2} \mathrm{SiO}_{4}\left(\alpha^{\prime}\right)$ with higher hydraulic reactivity in the final cement and it lowers the melting point of the raw mix which makes clinkering possible at lower temperatures $\left(\sim 1300^{\circ} \mathrm{C}\right)$ than typically used for Ordinary Portland cement (OPC) raw mixes $\left(\sim 1450^{\circ} \mathrm{C}\right)$ [4]. In order to be able to control and to optimize compositions and sintering conditions for these new raw mixes, a thorough knowledge of the underlying phase equilibria is desirable. Phase diagrams of the $\mathrm{CaO}-\mathrm{SiO}_{2}-\mathrm{Al}_{2} \mathrm{O}_{3}-\mathrm{Fe}_{2} \mathrm{O}_{3}-\mathrm{B}_{2} \mathrm{O}_{3}-\mathrm{SO}_{3}$ system and its sub-systems are needed. The focus in this contribution is on one of the $\mathrm{B}_{2} \mathrm{O}_{3}$ bearing sub-systems. While the phase equilibria in the lime rich part of the $\mathrm{CaO}-\mathrm{SiO}_{2}-\mathrm{B}_{2} \mathrm{O}_{3}$ ternary system are reasonably well established [5], this is not the case for the remaining ternary systems. Especially the $\mathrm{CaO}-\mathrm{Al}_{2} \mathrm{O}_{3}-\mathrm{B}_{2} \mathrm{O}_{3}$ system is of interest due to the high level of alumina in BYF type clinkers. In addition, other technical applications exist for compositions in this ternary system, for example in glasses with interesting optical [6], mechanical [7] and thermal properties [8]. The potential to form glasses in the ternary $\mathrm{CaO}-\mathrm{Al}_{2} \mathrm{O}_{3}-\mathrm{B}_{2} \mathrm{O}_{3}$ system is well known and the glass forming regions were investigated in the past [9]. In a recent publication by El-Hayek et al [10], the authors investigated the structure and properties of lime alumino-borate glasses in the $\mathrm{Ca}_{12} \mathrm{Al}_{14} \mathrm{O}_{33}$ - “ $\mathrm{Ca}_{12} \mathrm{~B}_{14} \mathrm{O}_{33}$ ” section.

Experimental information on phase equilibria in the ternary $\mathrm{CaO}-\mathrm{Al}_{2} \mathrm{O}_{3}-\mathrm{B}_{2} \mathrm{O}_{3}$ system are rare. Only one experimental phase diagram study is reported in the literature (Schäfer and Kuzel [11]). They investigated the ternary equilibria by synthesizing and analyzing 60 different samples. Two new ternary compounds, $\mathrm{CaO} \cdot \mathrm{Al}_{2} \mathrm{O}_{3} \cdot \mathrm{B}_{2} \mathrm{O}_{3}\left(\mathrm{CaAl}_{2} \mathrm{~B}_{2} \mathrm{O}_{7}\right)$ and $2 \mathrm{CaO} \cdot \mathrm{Al}_{2} \mathrm{O}_{3} \cdot \mathrm{B}_{2} \mathrm{O}_{3}\left(\mathrm{Ca}_{2} \mathrm{Al}_{2} \mathrm{~B}_{2} \mathrm{O}_{8}\right)$ where discovered. The samples were produced either by solid-state sintering or by re-crystallization of quenched amorphous liquids using $\mathrm{CaCO}_{3}, \mathrm{Al}_{2} \mathrm{O}_{3}$ and $\mathrm{H}_{3} \mathrm{BO}_{3}$ as starting materials. Typical sintering/crystallization conditions were temperatures ranging from $800^{\circ} \mathrm{C}$ to $1000^{\circ} \mathrm{C}$ and isothermal heat treatments of 60 to $100 \mathrm{~h}$. The melting behavior of the two ternary compounds were investigated using thermal analysis. Both compounds melt incongruently at $1098 \pm 10^{\circ} \mathrm{C}$ for $\mathrm{Ca}_{2} \mathrm{Al}_{2} \mathrm{~B}_{2} \mathrm{O}_{8}$, forming $\mathrm{CaAl}_{2} \mathrm{O}_{4}+$ a boron oxide rich liquid and at $1015 \pm 10^{\circ} \mathrm{C}$ for $\mathrm{CaAl}_{2} \mathrm{~B}_{2} \mathrm{O}_{7}$ forming $\mathrm{Al}_{18} \mathrm{~B}_{4} \mathrm{O}_{33}+\mathrm{a}$ boron oxide rich liquid. The crystal structures of the ternary compounds were investigated using X-ray powder diffraction. In addition, single crystals of the ternary compounds were prepared starting from homogeneous melts followed by slow cooling of the liquid phase 
with an overall composition in the primary crystallization field of the compounds. $\mathrm{Ca}_{2} \mathrm{Al}_{2} \mathrm{~B}_{2} \mathrm{O}_{8}$ has an orthorhombic unit cell with $a=8.27 \AA, b=15.23 \AA$ and $c=5.73 \AA$. The crystal structure of this ternary compound was later refined by Schuckman to the Ccc2 space group with a=8.269 $\AA$, $\mathrm{b}=15.227 \AA$ and $\mathrm{c}=5.733 \AA$ [12]. Ca has a 6-fold coordination, $\mathrm{Al}$ is in tetrahedral position and boron is surrounded by three oxygen atoms. The second ternary compound, $\mathrm{Ca}_{2} \mathrm{Al}_{2} \mathrm{~B}_{2} \mathrm{O}_{7}$, exists in two different structures. The stable modification at low temperature is hexagonal with $\mathrm{a}=4.81 \AA$ and $c=15.55 \AA$. The structure was later refined by Chang \& Keszler [13]. For temperatures below $830^{\circ} \mathrm{C}$, the crystal belongs to the R-3c space group with $\mathrm{a}=4.810 \AA$ and $\mathrm{c}=46.633 \AA$ in the hexagonal setting. The structure of the high temperature modification could only be determined on heat treated powder samples and the observed reflections were fitted to a monoclinic cell with $a=4.18 \mathrm{~A}, \mathrm{~b}=15.59 \mathrm{~A}, \mathrm{c}=8.16 \mathrm{~A}$ and $\beta=92.3$. However, the authors were not satisfied with their fit and claimed that further experimental work on single crystals was necessary to determine the structure of the high temperature modification with the needed precision.

Based on the results on the 60 different samples, the authors constructed an isothermal section of the $\mathrm{CaO}-\mathrm{Al}_{2} \mathrm{O}_{3}-\mathrm{B}_{2} \mathrm{O}_{3}$ diagram at $800^{\circ} \mathrm{C}$ (Fig.1). A third ternary compound, $\mathrm{Ca}_{2} \mathrm{Al}_{2} \mathrm{~B}_{6} \mathrm{O}_{14}$ (also called Johachidolite) was reported in the literature. It was first discovered by Iwase \& Saito [14] in natural mineral samples from North Korea. Moore \& Araki [15] confirmed the existence and that it belongs to the $\mathrm{CaO}-\mathrm{Al}_{2} \mathrm{O}_{3}-\mathrm{B}_{2} \mathrm{O}_{3}$ ternary system. They solved the crystal structure and attributed the formula $\mathrm{Ca}_{2} \mathrm{Al}_{2} \mathrm{~B}_{6} \mathrm{O}_{14}$ to the compound. The most recent crystal structure determination was performed by Kadiyski et al [16] on natural mineral samples from Myanmar. The compound is tetragonal (Cmma) with $a=7.967(2) \AA ̊, b=11.723(2) \AA ̊ n$ and $c=4.3718(5) \AA ̊$. Earlier attempts to synthesize this compound artificially under atmospheric pressure conditions failed $[17,18]$. Kadiyski et al attributed this fact to the very dense structure and they conclude that Johachidolite may only be stable under high pressure conditions. The structural properties of the three ternary compounds are summed up in Table 1.

Table 1: Structural properties of ternary compounds in the $\mathrm{CaO}-\mathrm{Al}_{2} \mathrm{O}_{3}-\mathrm{B}_{2} \mathrm{O}_{3}$ system

\begin{tabular}{|l|l|l|l|}
\hline $\begin{array}{l}\text { Phase / Temperature } \\
\text { range }\end{array}$ & $\begin{array}{l}\text { Space Group / } \\
\text { Pearson symbol }\end{array}$ & $\begin{array}{l}\text { Lattice parameter } \\
{[\AA]}\end{array}$ & Comments \\
\hline $\begin{array}{l}\mathrm{Ca}_{2} \mathrm{Al}_{2} \mathrm{~B}_{2} \mathrm{O}_{8} \\
<1098 \pm 10^{\circ} \mathrm{C}\end{array}$ & Ccc or Cccm & $\mathrm{a}=8.27$ \\
$\mathrm{~b}=15.23$ & $\mathrm{c}=5.73$ & $\begin{array}{l}\text { Schäfer \& Kuzel [11] } \\
\text { The space group is } \\
\text { tentative }\end{array}$ \\
\hline
\end{tabular}




\begin{tabular}{|c|c|c|c|}
\hline & $\begin{array}{l}\text { Ccc2 } \\
\text { Ccc2 }\end{array}$ & $\begin{array}{l}a=8.269 \\
b=15.227 \\
c=5.733 \\
a=8.24104 \\
b=15.22121 \\
c=5.74981\end{array}$ & $\begin{array}{l}\text { Schluckman [12] } \\
\text { Calculated [this work] }\end{array}$ \\
\hline $\begin{array}{l}\text { LT-CaAl }{ }_{2} \mathrm{~B}_{2} \mathrm{O}_{7} \\
<830^{\circ} \mathrm{C}\end{array}$ & $\begin{array}{l}\mathrm{P}_{3} 22 \\
\mathrm{R}-3 \mathrm{C} \\
\mathrm{R}-3 \mathrm{C}\end{array}$ & $\begin{array}{l}a=4.81 \\
c=15.55 \\
a=4.810 \\
c=46.633 \\
a=4.82093 \\
c=46.51937\end{array}$ & $\begin{array}{l}\text { Schäfer \& Kuzel [11] } \\
\text { The space group is } \\
\text { tentative } \\
\text { Chang \& Kezler [13] } \\
\text { Calculated [this work] }\end{array}$ \\
\hline $\begin{array}{l}\mathrm{HT}-\mathrm{CaAl}_{2} \mathrm{~B}_{2} \mathrm{O}_{7} \\
830^{\circ} \mathrm{C}<\mathrm{T}<1015 \pm 10^{\circ} \mathrm{C}\end{array}$ & Monoclinic & $\begin{array}{l}a=4.18 \\
b=15.56 \\
c=8.16 \\
\beta=92.3\end{array}$ & Schäfer \& Kuzel [11] \\
\hline $\mathrm{Ca}_{2} \mathrm{Al}_{2} \mathrm{~B}_{6} \mathrm{O}_{14}$ & $\begin{array}{l}\text { Cmma } \\
\text { Cmma }\end{array}$ & $\begin{array}{l}a=7.967(2) \\
b=11.723(2) \\
c=4.3718(5) \\
a=7.94636 \\
b=11.70456 \\
c=4.36109\end{array}$ & $\begin{array}{l}\text { Kadiyski et al [16] } \\
\text { Calculated [this work] }\end{array}$ \\
\hline
\end{tabular}




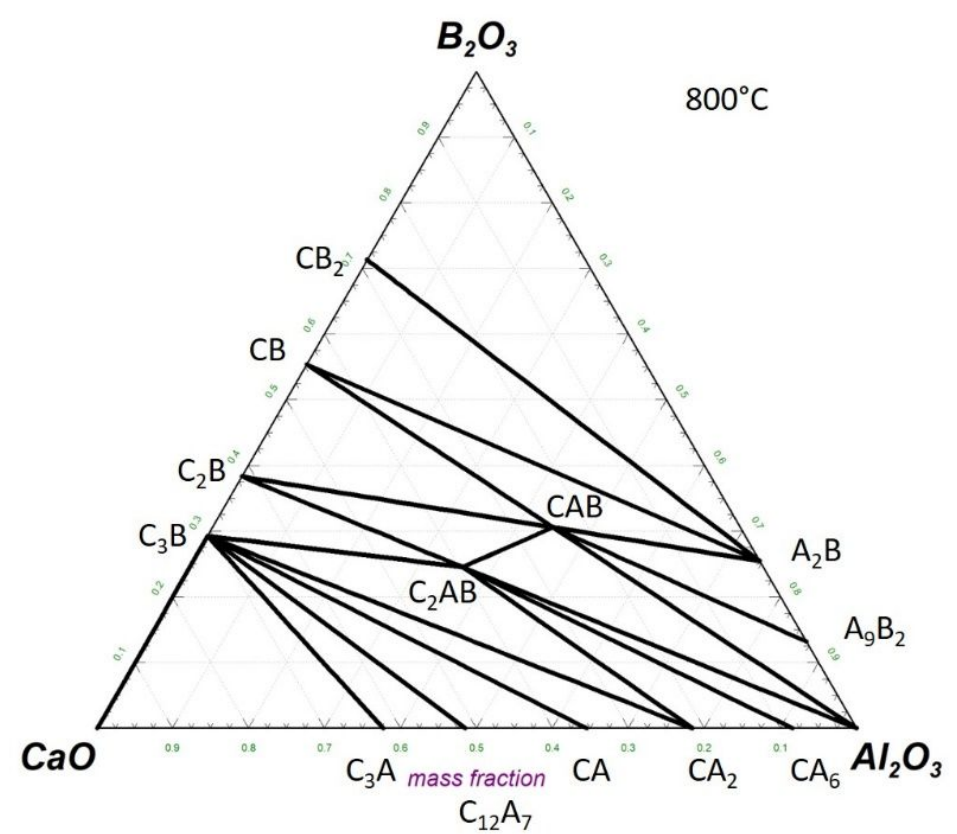

Fig. 1: Experimental isothermal section of the $\mathrm{CaO}-\mathrm{Al}_{2} \mathrm{O}_{3}-\mathrm{B}_{2} \mathrm{O}_{3}$ system at $800^{\circ} \mathrm{C}$ reproduced using the data from Schäfer and Kuzel [10]

The experimental phase diagram from Schäfer and Kuzel can be compared to a calculated isothermal section using the FactSage Gibbs energy minimizing software [19] and the FTOxid thermodynamic database in its most recent version (7.3). In the documentation of the FTOxid database, it is claimed that the Gibbs energy data for the $\mathrm{CaO}-\mathrm{Al}_{2} \mathrm{O}_{3}-\mathrm{B}_{2} \mathrm{O}_{3}$ ternary system is fully assessed. The calculated isothermal section at $800^{\circ} \mathrm{C}$ is presented in Fig.2. The experimental and calculated diagrams differ in several points. In the calculated diagram, a lime rich liquid phase is observed in equilibrium with $\mathrm{CaO}, \mathrm{Ca}_{3} \mathrm{Al}_{2} \mathrm{O}_{6}, \mathrm{CaAl}_{2} \mathrm{O}_{4}$ and $\mathrm{Ca}_{2} \mathrm{~B}_{2} \mathrm{O}_{5}$. This liquid phase is not observed experimentally and its existence is highly unlikely because it would correspond to an extremely steep liquidus slope from pure $\mathrm{CaO}$ (melting point at $2949^{\circ} \mathrm{C}$ ) to a ternary eutectic calculated at $677^{\circ} \mathrm{C}$. The second difference is the absence of $\mathrm{Ca}_{12} \mathrm{Al}_{14} \mathrm{O}_{33}$ in the calculated diagram. The third difference involves the $\mathrm{CaAl}_{2} \mathrm{~B}_{2} \mathrm{O}_{7}$ ternary compound. In the experimental diagram, a three phase equilbrium $\mathrm{CaAl}_{2} \mathrm{~B}_{2} \mathrm{O}_{7}+\mathrm{CaB}_{2} \mathrm{O}_{4}+\mathrm{Al}_{4} \mathrm{~B}_{2} \mathrm{O}_{9}$ is proposed while in the calculated diagram, the three phase equilbrium is $\mathrm{CaAl}_{2} \mathrm{~B}_{2} \mathrm{O}_{7}+\mathrm{CaB}_{4} \mathrm{O}_{7}+\mathrm{Al}_{4} \mathrm{~B}_{2} \mathrm{O}_{9}$. The fourth and last difference concerns the $\mathrm{B}_{2} \mathrm{O}_{3}$ rich corner for which a distinct solubility of $\mathrm{CaO}$ and $\mathrm{Al}_{2} \mathrm{O}_{3}$ in liquid $\mathrm{B}_{2} \mathrm{O}_{3}$ is proposed. It is obvious that the agreement between the calculated and experimental isothermal section is poor, 
however it may not straightforward to judge if the difference comes from errors in the thermodynamic description or lies in the experimental determination of the diagram.

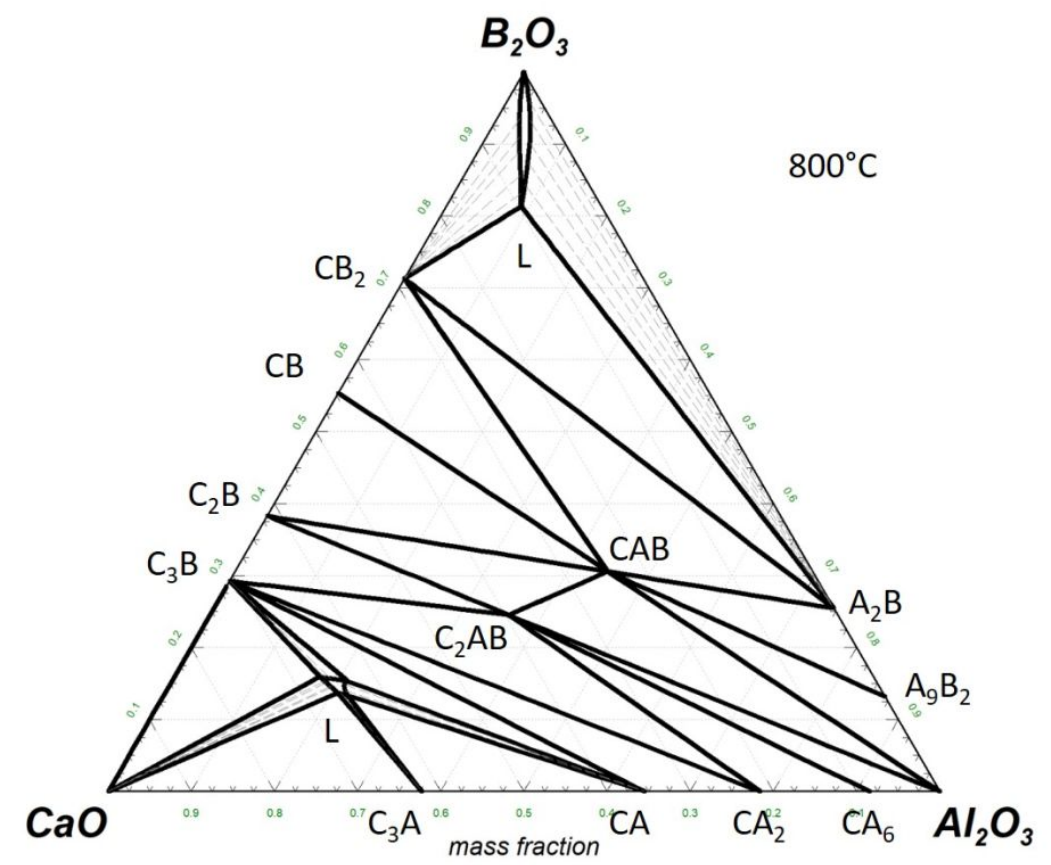

Fig.2: Calculated isothermal section of the $\mathrm{CaO}-\mathrm{Al}_{2} \mathrm{O}_{3}-\mathrm{B}_{2} \mathrm{O}_{3}$ system at $800^{\circ} \mathrm{C}$ using thermodynamic data from the FTOxid database and the FactSage Gibbs energy minimizer (v.7.3) [19]. L corresponds to the liquid phase ; compounds in reduced notation $\mathrm{C}=\mathrm{CaO}, \mathrm{A}=\mathrm{Al}_{2} \mathrm{O}_{3}, \mathrm{~B}=\mathrm{B}_{2} \mathrm{O}_{3}$.

The purpose of this contribution is to re-investigate experimentally the phase equilbria in the $\mathrm{CaO}-\mathrm{Al}_{2} \mathrm{O}_{3}-\mathrm{B}_{2} \mathrm{O}_{3}$ ternary system with a focus on the lime rich part of the diagram. Phase diagram data for the three binary boundary systems were accepted from the literature. The phase diagram of the $\mathrm{CaO}-\mathrm{B}_{2} \mathrm{O}_{3}$ system was established by Carlson [20]. Four solid compounds are present in the system: $\mathrm{Ca}_{3} \mathrm{~B}_{2} \mathrm{O}_{6}, \mathrm{Ca}_{2} \mathrm{~B}_{2} \mathrm{O}_{5}, \mathrm{CaB}_{2} \mathrm{O}_{4}$ and $\mathrm{CaB}_{4} \mathrm{O}_{7}$. Data for the $\mathrm{Al}_{2} \mathrm{O}_{3}-\mathrm{B}_{2} \mathrm{O}_{3}$ binary system is less reliable. The recent review of the available experimental data and thermodynamic modeling of Decterov et al [21] was accepted for this study. Two solid compounds are present at equilibrium, $\mathrm{Al}_{19} \mathrm{~B}_{4} \mathrm{O}_{33}$ and $\mathrm{Al}_{4} \mathrm{~B}_{2} \mathrm{O}_{9}$. Additional compounds were reported in literature [22], most of them being synthesized at low temperature by sol-gel methods. It appears that these compounds transform into the two equilibrium phases when heated at higher temperatures. Two versions of the CaO$\mathrm{Al}_{2} \mathrm{O}_{3}$ binary phase diagram exist in the literature. The difference is the presence or not of $\mathrm{Ca}_{12} \mathrm{Al}_{14} \mathrm{O}_{33}$. The compound is absent in a purified atmosphere $\left(\mathrm{O}_{2}, \mathrm{~N}_{2}\right)[23,24]$, but present when 
the phase diagram studies were performed in air $[25,26]$. The pure oxide compound $\mathrm{Ca}_{12} \mathrm{Al}_{14} \mathrm{O}_{33}$ may therefore be the end member of the solid solution $\mathrm{Ca}_{12} \mathrm{Al}_{13} \mathrm{O}_{32}\left(\mathrm{O}_{1},(\mathrm{OH})_{2}\right)_{1}$ and this end member seems to be unstable in the $\mathrm{CaO}-\mathrm{Al}_{2} \mathrm{O}_{3}$ system under water free conditions.

There is no thermodynamic data available for the three ternary compounds. Therefore, their heat of formation and their heat capacities were calculated using Density Functional Theory (DFT) and lattice dynamics theory (Phonons). These theoretical data was used to calculate theoretical phase diagrams which were then compared to the experimental data.

\section{Theory}

The thermodynamic properties of the three ternary compounds, $\mathrm{CaAl}_{2} \mathrm{~B}_{2} \mathrm{O}_{7}, \mathrm{Ca}_{2} \mathrm{Al}_{2} \mathrm{~B}_{2} \mathrm{O}_{8}$ and $\mathrm{Ca}_{2} \mathrm{Al}_{2} \mathrm{~B}_{6} \mathrm{O}_{14}$, with respect to their constitutive simple oxides, $\mathrm{CaO}, \mathrm{Al}_{2} \mathrm{O}_{3}$ and $\mathrm{B}_{2} \mathrm{O}_{3}$, were determined using density functional theory (DFT) $[27,28]$ as implemented in the VASP (Vienna Ab-Initio Software) package $[29,30]$. The most recent version of VASP $(5.4 .4)$ was used for this study.

The recently developed semi-local density functional SCAN (Strongly Constrained and Appropriately Normed) [31] was used here to determine the ground state properties of all compounds at $0 \mathrm{~K}$. The SCAN functional is to known to allow more accurate total energy calculations in oxide systems as compared to results obtained with classical GGA or LDA functionals [32]. For $\mathrm{Ca}$, the $3 p, 3 s$ and $4 p$ orbitals, for $\mathrm{Al}$, the $3 p$ and 3 s orbitals and for $\mathrm{B}$ and $0,2 \mathrm{p}$ and $2 \mathrm{~s}$ orbitals are considered as valence states in the calculation. The cut-off energy for the projector augmented bands was set to $700 \mathrm{eV}$. A gamma-centered k-point grid in the irreducible part of the Brillouin zone was used. This grid was automatically generated and follows the Monkhorst-Pack scheme [33]. The k-points grids for the compounds were: $10 \times 10 \times 1$ for $\mathrm{CaAl}_{2} \mathrm{~B}_{2} \mathrm{O}_{7}$, $4 \times 2 \times 6$ for $\mathrm{Ca}_{2} \mathrm{Al}_{2} \mathrm{~B}_{2} \mathrm{O}_{8}$ and $2 \times 2 \times 5$ for $\mathrm{Ca}_{2} \mathrm{Al}_{2} \mathrm{~B}_{6} \mathrm{O}_{14}$. Lattice parameters and internal atomic coordinates were fully relaxed. The electronic density of state (DOS) was calculated using the linear tetrahedron method with Blöchl corrections [34]. The relaxation calculations were performed with an energy criterion of $10^{-8} \mathrm{eV} / \mathrm{A}$. Zero-point energies (ZPE) and derived heat capacities at constant volume (harmonic approximation) and pressure (quasi-harmonic approximation) were determined using lattice dynamics theory. Phonon spectra of all compounds were calculated using the frozen phonon / supercell method as implemented in phonopy [35]. The supercells were $1 \times 1 \times 2$ for $\mathrm{CaAl}_{2} \mathrm{~B}_{2} \mathrm{O}_{7}, 4 \times 2 \times 6$ for $\mathrm{Ca}_{2} \mathrm{Al}_{2} \mathrm{~B}_{2} \mathrm{O}_{8}$ and $3 \times 2 \times 5$ for $\mathrm{Ca}_{2} \mathrm{Al}_{2} \mathrm{~B}_{6} \mathrm{O}_{14}$. The convergence criteria for the Hellman-Feynman forces was set to $10^{-6} \mathrm{eV} / \AA ̊ \AA$ to avoid any kind of residual stress in the lattice. 


\section{Experimental}

The raw material for $\mathrm{CaO}$ was pure limestone $\mathrm{CaCO}_{3}(99 \%$, GPR Reactapur - VWR Prolabo) and for $\mathrm{Al}_{2} \mathrm{O}_{3}$ pure corundum (99\%, VWR Prolabo). Concentrated boron compounds are classified as carcinogenic, mutagenic or toxic to reproduction (CMR) and therefore boric acid $\mathrm{H}_{3} \mathrm{BO}_{3}$ was avoided as starting material. Because the purpose of the study is to investigate lime-rich compositions, it was decided to use solid Calcium metaborate $\mathrm{CaB}_{2} \mathrm{O}_{4}\left(39-44 \% \mathrm{~B}_{2} \mathrm{O}_{3}\right.$, Sigma Aldrich) instead. The boron content of the sample was checked by ICP analysis and a value of $39.6 \%$ was found which is within the specification given by the supplier.

Pure $\mathrm{Ca}_{3} \mathrm{Al}_{2} \mathrm{O}_{6}$ and $\mathrm{CaAl}_{2} \mathrm{O}_{4}$ were prepared for further processing. Appropriate amounts of $\mathrm{CaCO}_{3}$ and $\mathrm{Al}_{2} \mathrm{O}_{3}$ were mixed under wet conditions and pressed into pellets. The pellets were then dried for $12 \mathrm{~h}$ at $105^{\circ} \mathrm{C}$ and fired in a static muffle furnace in air with a two-step temperature profile. The first step was identical for the two samples and corresponds to the calcination of limestone. An isothermal treatment of $1 \mathrm{~h}$ at $900^{\circ} \mathrm{C}$ led to the complete loss of $\mathrm{CO}_{2}(\mathrm{~g})$. The sintering step was performed at $1450^{\circ} \mathrm{C}$ and $12 \mathrm{~h}$ for $\mathrm{Ca}_{3} \mathrm{Al}_{2} \mathrm{O}_{6}$ and at $1500^{\circ} \mathrm{C}$ and $12 \mathrm{~h}$ for $\mathrm{CaAl}_{2} \mathrm{O}_{4}$ followed by slow air-cooling in the furnace. Metallic crucibles with lids made of Pt-10\%Rh were used for the sintering and all heat treatments to avoid any contamination and to minimize evaporation of boron. No reaction between the samples and the crucible were observed. Weight losses were recorded as the difference in initial and final weight of all sample in all experiments to estimate any boron evaporation. The cooled samples were ground in an agate mortar to a fineness $<63 \mu \mathrm{m}$ for further processing. The purity of the samples was checked with X-Ray diffraction using the Ka radiation of a $\mathrm{Cu}$ tube in $\theta-2 \theta$ mode.

For the phase diagram study as a function of temperature, sample compositions were defined along two sections, $\mathrm{Ca}_{3} \mathrm{Al}_{2} \mathrm{O}_{6}-\mathrm{CaB}_{2} \mathrm{O}_{4}$ and $\mathrm{CaAl}_{2} \mathrm{O}_{4}-\mathrm{CaB}_{2} \mathrm{O}_{4}$. Appropriate amounts of ground samples of the Ca-aluminates and the Ca-metaborate were mixed together and pressed into pellets. The composition of the sample as well as the thermal treatment conditions are summed up in Table 2. 
Table 2: Compositions $\left(\mathrm{C}=\mathrm{CaO}, \mathrm{A}=\mathrm{Al}_{2} \mathrm{O}_{3}, \mathrm{~B}=\mathrm{B}_{2} \mathrm{O}_{3}\right)$ and experimental conditions for all samples used in this contribution

\begin{tabular}{|l|c|c|c|c|c|}
\hline \multicolumn{3}{|l|}{ wt.\% } & \multicolumn{2}{l|}{ Thermal treatment } \\
\hline Sample & $\mathrm{CaO}$ & $\mathrm{B}_{2} \mathrm{O}_{3}$ & $\mathrm{Al}_{2} \mathrm{O}_{3}$ & $\mathrm{~T}\left[{ }^{\circ} \mathrm{C}\right]$ & Holding time $[\mathrm{h}]$ \\
\hline 90CA_10CB & 36.4 & 5.5 & 58.1 & 950 & 240 \\
\hline 80CA_20CB & 37.3 & 11.1 & 51.6 & 950 & 240 \\
\hline 50CA_50CB & 40.0 & 27.7 & 32.3 & 950 & 240 \\
\hline 30CA_70CB & 41.9 & 38.8 & 19.4 & 950 & 240 \\
\hline 85C3A_15CB & 59.6 & 8.3 & 32.1 & 950 & 240 \\
\hline 75C3A_25CB & 57.9 & 13.8 & 28.3 & 1020 & 90 \\
\hline 68C3A_32CB & 56.6 & 17.7 & 25.7 & 1020 & 90 \\
\hline 60C3A_40CB & 55.2 & 22.2 & 22.6 & 1020 & 90 \\
\hline 50C3A_50CB & 53.4 & 27.7 & 18.9 & 1020 & 90 \\
\hline 40C3A_60CB & 51.7 & 33.2 & 15.1 & 950 & 240 \\
\hline 30C3A_70CB & 49.9 & 38.8 & 11.3 & 950 & 240 \\
\hline Ter_70C_10B_20A & 69.9 & 10.2 & 19.9 & 1020 & 90 \\
\hline Ter_30C_55B_55A & 25.1 & 15.0 & 54.9 & 1020 & 90 \\
\hline Ter_25C_25B_50A & 25.1 & 24.9 & 50.0 & 1020 & 90 \\
\hline
\end{tabular}

In addition, three ternary compositions as well as the two reported stable ternary compounds, $\mathrm{Ca}_{2} \mathrm{Al}_{2} \mathrm{~B}_{2} \mathrm{O}_{8}$ and $\mathrm{CaAl}_{2} \mathrm{~B}_{2} \mathrm{O}_{7}$ were prepared by weighing and mixing appropriate amounts of $\mathrm{CaCO}_{3}$, $\mathrm{Al}_{2} \mathrm{O}_{3}$ and $\mathrm{CaB}_{2} \mathrm{O}_{4}$. The different raw mixes were pressed into pellets and sintered at $1020^{\circ} \mathrm{C}$ for 190h. The mineralogical compositions of all samples were determined by X-ray diffraction.

Thermal analysis was performed on all samples using a Setaram Setsys Evolution apparatus and the DSC (Differential Scanning Calorimetry) measuring tip. The equipment was calibrated on temperature with the fusion temperatures of $\mathrm{NaCl}, \mathrm{KCl}, \mathrm{K}_{2} \mathrm{SO}_{4}$ and $\mathrm{CaF}_{2}$. A typical amount of $50 \mathrm{mg}$ of each sample was placed in platinum crucibles and covered with a platinum lid. All measurements were performed with a heating rate of $5 \mathrm{~K} / \mathrm{min}$ from room temperature up to $1450^{\circ} \mathrm{C}$ directly followed by a cooling step with the same rate and under flowing Ar with a flow rate of $20 \mathrm{~mL} / \mathrm{min}$. The baseline correction was performed by a thermal run with empty crucibles in both measurement chambers. The estimation of the experimental error of all measured temperatures in this contribution is $\pm 5 \mathrm{~K}$. The reported invariant temperatures correspond to the 
onset of the endothermal peaks in the heat flow curves. The liquidus temperatures correspond to the return to the baseline at high temperature. The exact values were determined by derivation of the heat flow curve.

\section{Results and discussion}

\section{Thermodynamic properties}

The calculated lattice parameters corresponding to the fully relaxed atomic positions in the three ternary compounds are presented in Table 1 . The overall agreement with the experimentally observed lattice parameters is good.

The calculated ground state energies and zero-point energies (ZPE) for the simple oxides and the three ternary compounds are presented in Table 3 . The energy of formation $\Delta \mathrm{E}(0 \mathrm{~K})$ of all three ternary compounds are negative, i.e. they are stable at $0 \mathrm{~K}$ with respect to the three constituting simple oxides in their respective ground state.

Table 3 : Thermodynamic properties at 0K from DFT calculations using the SCAN functional

\begin{tabular}{|l|l|l|l|l|}
\hline Compound & $\begin{array}{l}\mathrm{E}(0 \mathrm{~K}) \\
{[\mathrm{kJ} / \mathrm{mol}]}\end{array}$ & $\begin{array}{l}\mathrm{ZPE} \\
{[\mathrm{kJ} / \mathrm{mol}]}\end{array}$ & & \\
\hline $\mathrm{CaO}$ & -2157.258 & 10.010 & & \\
\hline $\mathrm{Al}_{2} \mathrm{O}_{3}$ & -4929.612 & 45.545 & & \\
\hline $\mathrm{B}_{2} \mathrm{O}_{3}$ & -4488.856 & 64.163 & & \\
\hline & & & $\Delta \mathrm{E}(0 \mathrm{~K})$ & $\begin{array}{l}\mathrm{ZPE}(0 \mathrm{~K}) \\
{[\mathrm{kJ} / \mathrm{mol}]}\end{array}$ \\
& & & -104.455 & -4.783 \\
\hline $\mathrm{CaAl}_{2} \mathrm{~B}_{2} \mathrm{O}_{7}(\mathrm{CAB})$ & -11680.181 & 114.935 & -168.710 & -2.982 \\
\hline $\mathrm{Ca}_{2} \mathrm{Al}_{2} \mathrm{~B}_{2} \mathrm{O}_{8}\left(\mathrm{C}_{2} \mathrm{AB}\right)$ & -13902.534 & 126.747 & -331.688 & -1.715 \\
\hline $\mathrm{Ca}_{2} \mathrm{Al}_{2} \mathrm{~B}_{6} \mathrm{O}_{14}\left(\mathrm{C}_{2} \mathrm{AB}{ }_{3}\right)$ & -23042.385 & 256.340 & & \\
\hline
\end{tabular}

The heat capacity at constant pressure in the quasi-harmonic approximation, as compared to Neumann \& Kopp's additive rule are presented in Figures 3-5 for the three ternary compounds. 


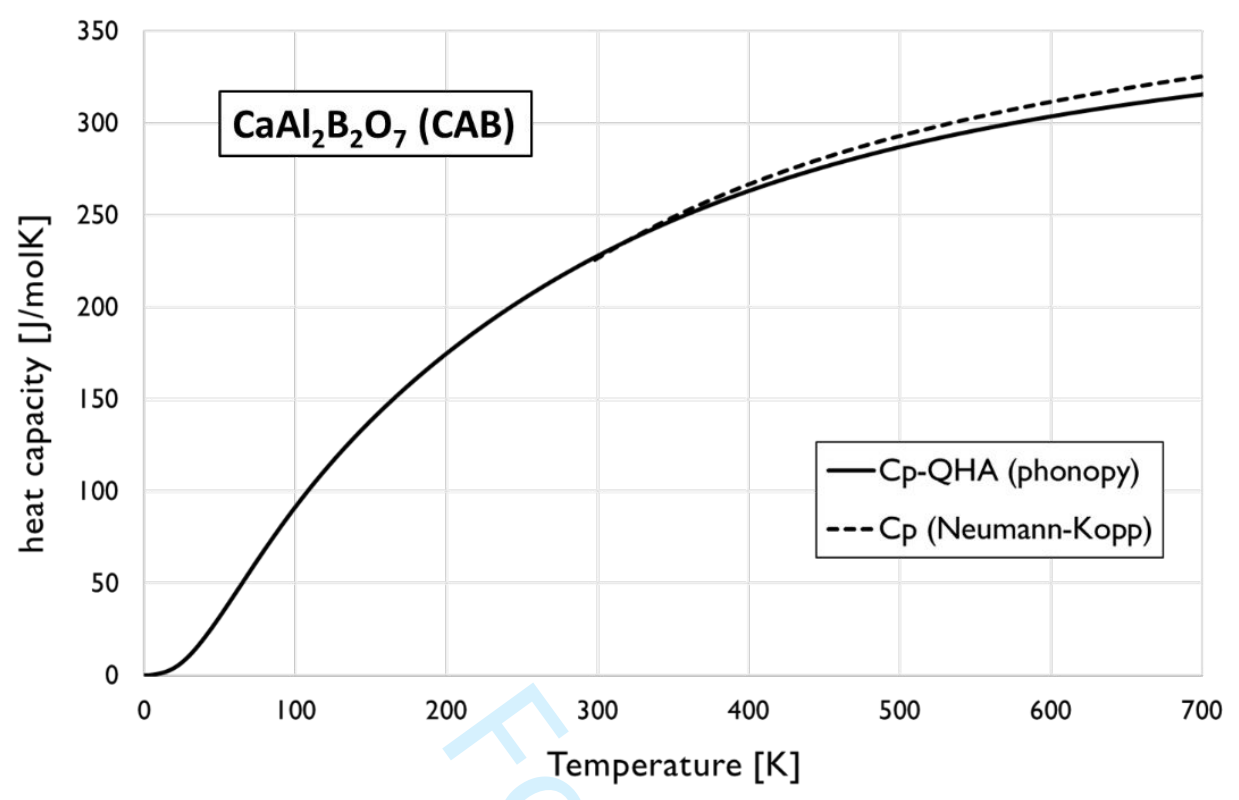

Fig 3: Calculated heat capacity at constant pressure in the quasi-harmonic approximation for $\mathrm{CaAl}_{2} \mathrm{~B}_{2} \mathrm{O}_{7}$ (full line) as compared to Neumann-Kopp's additive rule (dotted line) using data from the Factsage pure substance database for $\mathrm{CaO}, \mathrm{Al}_{2} \mathrm{O}_{3}$ and $\mathrm{B}_{2} \mathrm{O}_{3}$.

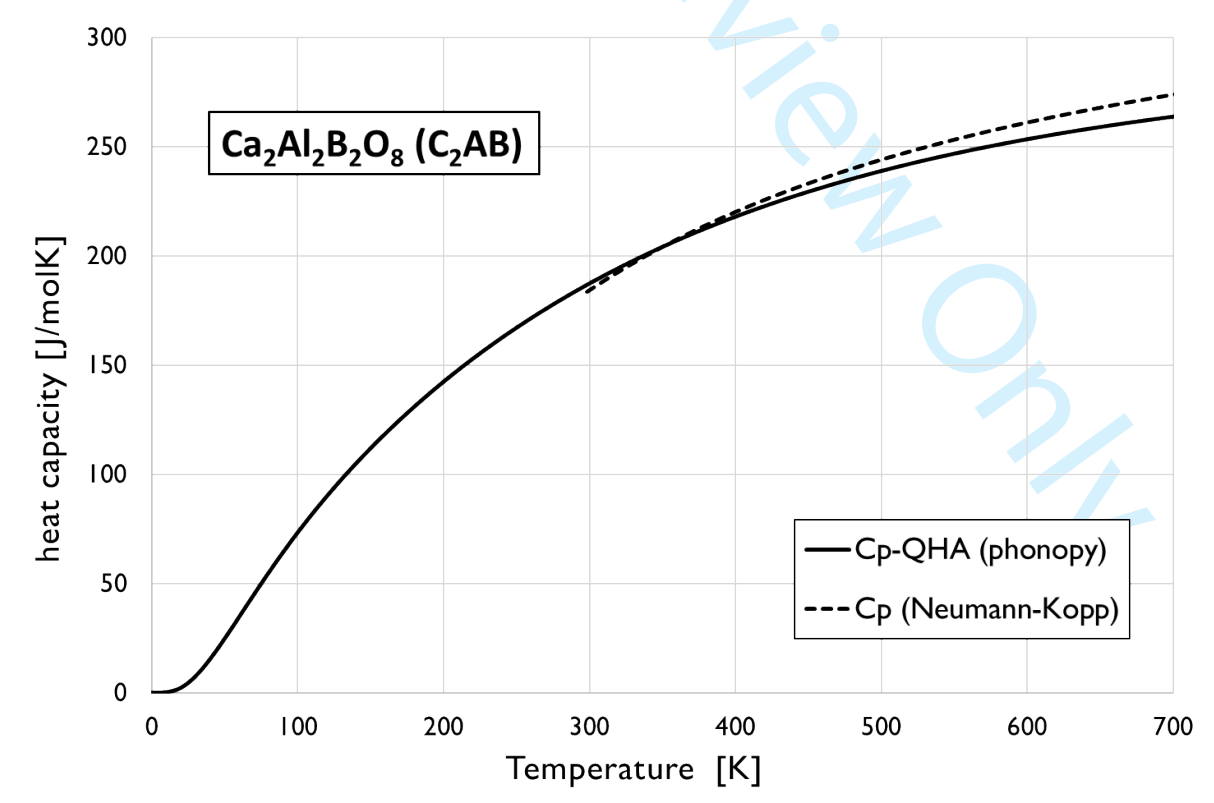

Fig 4: Calculated heat capacity at constant pressure in the quasi-harmonic approximation for $\mathrm{Ca}_{2} \mathrm{Al}_{2} \mathrm{~B}_{2} \mathrm{O}_{8}$ (full line) as compared to Neumann-Kopp's additive rule (dotted line) using data from the Factsage pure substance database for $\mathrm{CaO}, \mathrm{Al}_{2} \mathrm{O}_{3}$ and $\mathrm{B}_{2} \mathrm{O}_{3}$. 


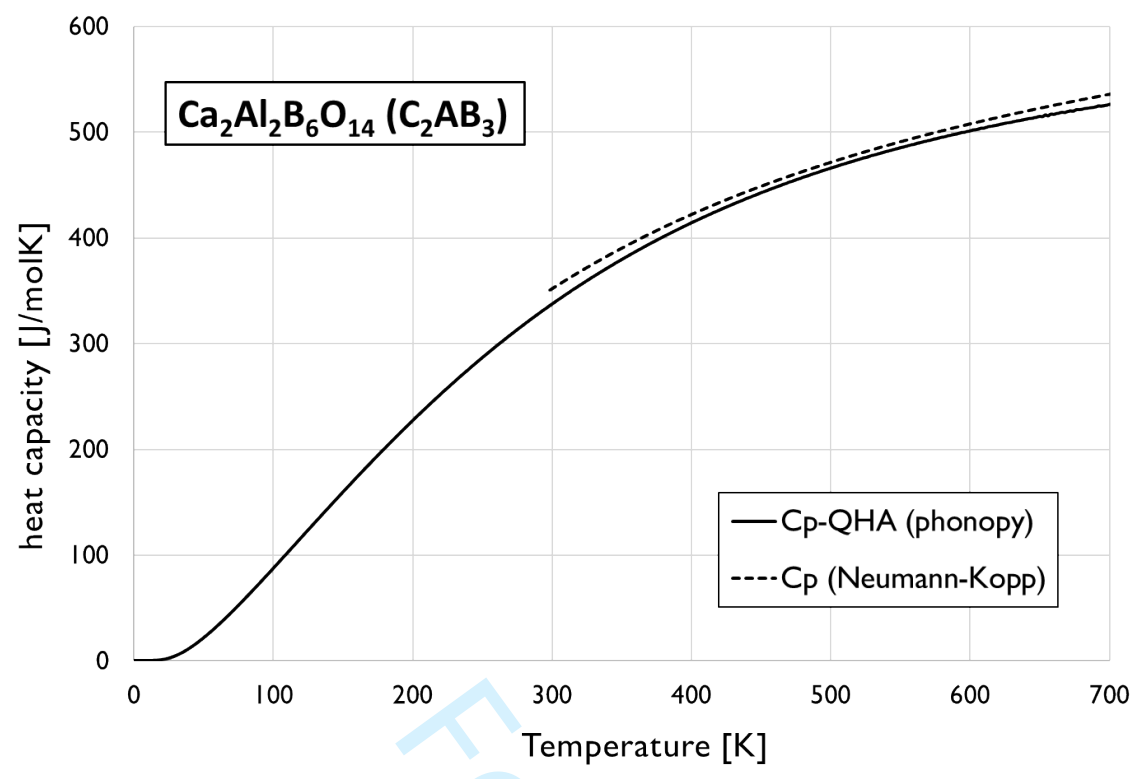

Fig 5: Calculated heat capacity at constant pressure in the quasi-harmonic approximation for $\mathrm{Ca}_{2} \mathrm{Al}_{2} \mathrm{~B}_{6} \mathrm{O}_{14}$ (full line) as compared to Neumann-Kopp's additive rule (dotted line) using data from the Factsage pure substance database for $\mathrm{CaO}, \mathrm{Al}_{2} \mathrm{O}_{3}$ and $\mathrm{B}_{2} \mathrm{O}_{3}$.

For $\mathrm{CaAl}_{2} \mathrm{~B}_{2} \mathrm{O}_{7}$ and $\mathrm{Ca}_{2} \mathrm{Al}_{2} \mathrm{~B}_{2} \mathrm{O}_{8}$ the calculated heat capacity is close to the sum of the simple oxides up to $\sim 350 \mathrm{~K}$. At higher temperatures, the calculated heat capacity is below the Neumann \& Kopp's one. As already mentioned above, there is unfortunately now experimental data available with which the calculated theoretical values could be compared. However, as the atomic positions in both structures are not high symmetry ones $[12,13]$, anharmonic contributions are likely to occur at higher temperatures. The calculated heat capacity at temperatures above $350 \mathrm{~K}$ may therefore act as a lower boundary to the true heat capacity at high temperature.

In the case of $\mathrm{Ca}_{2} \mathrm{Al}_{2} \mathrm{~B}_{6} \mathrm{O}_{14}$, the situation is different. Already at room temperature, the heat capacity is $\sim 15 \mathrm{~J} / \mathrm{mol} \mathrm{K}$ below the additive rule curve. This difference remains almost the same value at higher temperature.

From the low temperature heat capacity in the $0-298 \mathrm{~K}$ interval, one can derive the standard entropy at $298 \mathrm{~K}$ and the heat content $\mathrm{H}(298 \mathrm{~K})-\mathrm{H}(0 \mathrm{~K})$ by numerical integration of the calculated values. The thermodynamic properties in the standard state are presented in Table 4. The thermodynamic properties referred to the simple oxides and compared to the commercial Factsage databases (FTPs/FTOxid) are gathered in Table 5. The thermodynamic data for the simple oxides were again taken from the Factsage pure substance database. 


\begin{tabular}{|c|c|c|c|c|}
\hline compound & $\begin{array}{l}\Delta \mathrm{H} \\
\mathrm{kJ} / \mathrm{mol}\end{array}$ & $\begin{array}{l}\mathrm{S} \\
\mathrm{J} / \mathrm{molK}\end{array}$ & $\begin{array}{l}\mathrm{Cp} \\
\mathrm{J} / \mathrm{molK}\end{array}$ & $\begin{array}{l}\mathrm{H}(298)-\mathrm{H}(0) \\
\mathrm{kJ} / \mathrm{mol}\end{array}$ \\
\hline $\mathrm{CaO}$ & -635.090 & 37.75 & 42.12 & 6.749 \\
\hline $\mathrm{Al}_{2} \mathrm{O}_{3}$ & -1678.700 & 50.82 & 79.02 & 10.020 \\
\hline $\mathrm{B}_{2} \mathrm{O}_{3}$ & -1271.900 & 53.95 & 65.59 & 9.293 \\
\hline $\mathrm{CaAl}_{2} \mathrm{~B}_{2} \mathrm{O}_{7}$ & -3687.834 & 181.83 & 185.85 & 30.156 \\
\hline $\mathrm{Ca}_{2} \mathrm{Al}_{2} \mathrm{~B}_{2} \mathrm{O}_{8}$ & -4385.479 & 227.65 & 227.20 & 36.805 \\
\hline $\mathrm{Ca}_{2} \mathrm{Al}_{2} \mathrm{~B}_{60}$ & -7099.743 & 257.56 & 335.46 & 46.637 \\
\hline
\end{tabular}

Table 5: Thermodynamic properties of the three ternary compounds as referred to the simple oxides and compared to the values stored in the commercial Factsage databases (FTPs/FTOxid) .

\begin{tabular}{|l|l|l|l|l|}
\hline compound & $\Delta \mathrm{H}$ & $\Delta \mathrm{S}$ & $\Delta \mathrm{Cp}$ & Reference \\
& $\mathrm{kJ} / \mathrm{mol}$ & $\mathrm{J} / \mathrm{molK}$ & $\mathrm{J} / \mathrm{molK}$ & \\
\hline $\mathrm{CaAl}_{2} \mathrm{~B}_{2} \mathrm{O}_{7}$ & -105.14 & 39.31 & 2.16 & This work \\
& -143.81 & 13.30 & -0.69 & FTPS 7.3 \\
\hline $\mathrm{Ca}_{2} \mathrm{Al}_{2} \mathrm{~B}_{2} \mathrm{O}_{8}$ & -167.70 & 47.38 & 1.49 & This work \\
& -218.22 & 13.30 & -0.69 & FTPS 7.3 \\
\hline $\mathrm{Ca}_{2} \mathrm{Al}_{2} \mathrm{~B}_{6} \mathrm{O}_{14}$ & -338.16 & -30.61 & -15.522 & This work \\
\hline
\end{tabular}

Using this new thermodynamic data for the ternary compounds, one can calculate the phase equilibria in the ternary $\mathrm{CaO}-\mathrm{Al}_{2} \mathrm{O}_{3}-\mathrm{B}_{2} \mathrm{O}_{3}$ system. The calculated isothermal section at $25^{\circ} \mathrm{C}$ is presented in Fig. 6 and the one calculated at $950^{\circ} \mathrm{C}$ in Fig 7. For the high temperature, the validity of Neumann-Kopp's rule was assumed for the heat content of $\mathrm{CaAl}_{2} \mathrm{~B}_{2} \mathrm{O}_{7}$ and $\mathrm{Ca}_{2} \mathrm{Al}_{2} \mathrm{~B}_{2} \mathrm{O}_{8}$ (i.e. $\Delta \mathrm{Cp}=0$ with respect to the simple oxides) and for $\mathrm{Ca}_{2} \mathrm{Al}_{2} \mathrm{~B}_{6} \mathrm{O}_{14}$ the constant $\Delta \mathrm{Cp}$ reported in Table 5 was 
adopted in the full temperature range. The Gibbs energy data for the binary compounds for the phase diagram calculations were taken from the Factsage substance database.

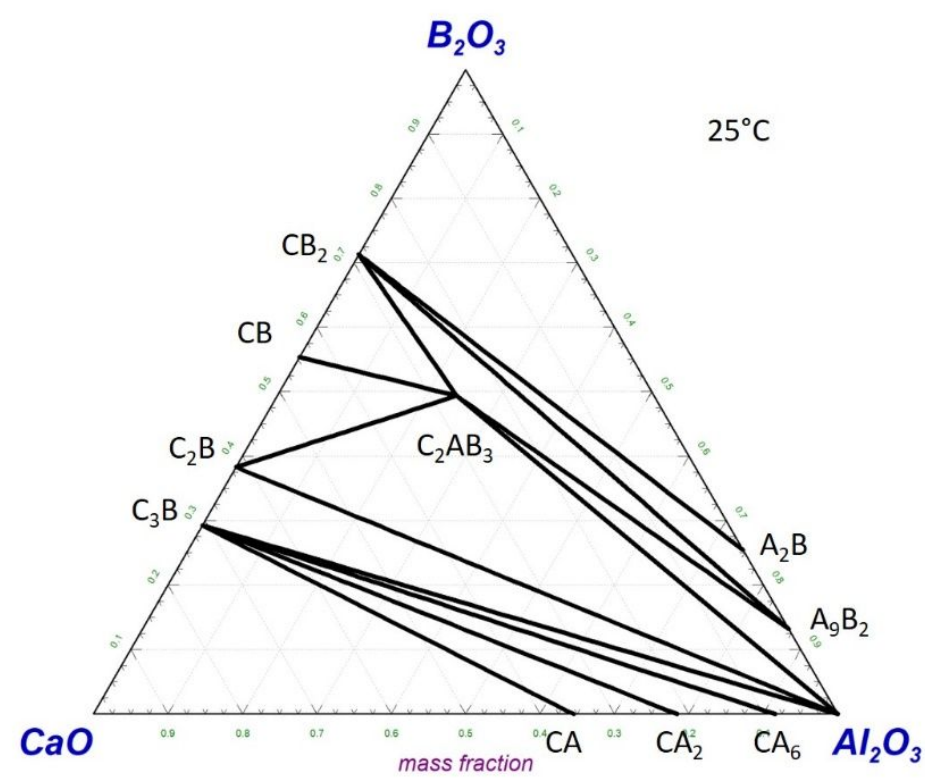

Fig. 6 : Calculated isothermal section of the $\mathrm{CaO}-\mathrm{Al}_{2} \mathrm{O}_{3}-\mathrm{B}_{2} \mathrm{O}_{3}$ system at $25^{\circ} \mathrm{C}\left(\mathrm{C}=\mathrm{CaO}, \mathrm{A}=\mathrm{Al} 2 \mathrm{O}_{3}\right.$, $\left.\mathrm{B}=\mathrm{B}_{2} \mathrm{O}_{3}\right)$

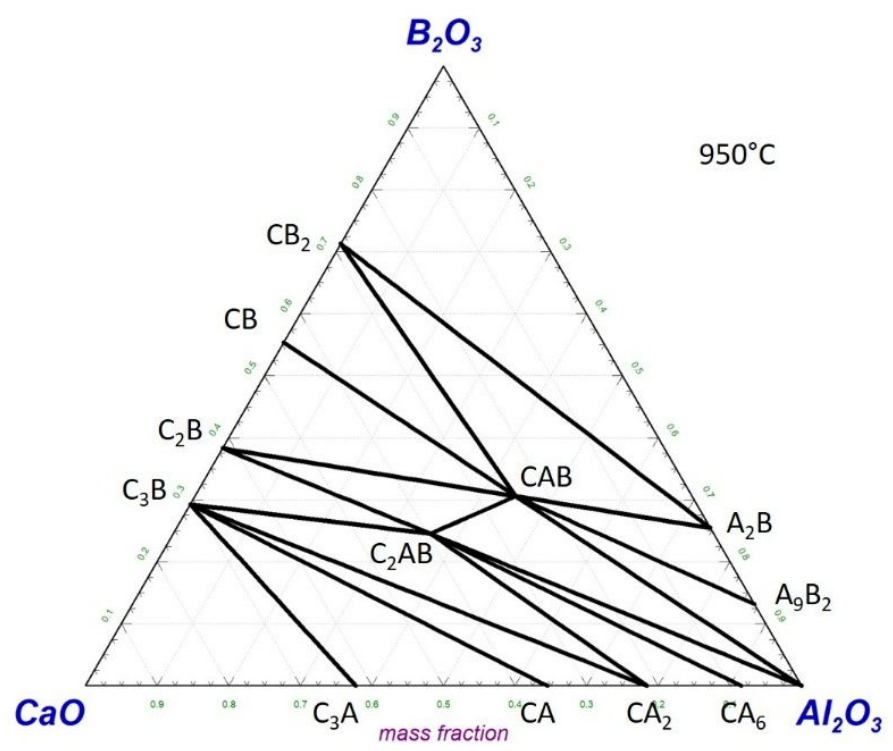


Fig 7: Calculated isothermal section of the $\mathrm{CaO}-\mathrm{Al}_{2} \mathrm{O}_{3}-\mathrm{B}_{2} \mathrm{O}_{3}$ system at $950^{\circ} \mathrm{C}\left(\mathrm{C}=\mathrm{CaO}, \mathrm{A}=\mathrm{Al} 2 \mathrm{O}_{3}\right.$, $\left.\mathrm{B}=\mathrm{B}_{2} \mathrm{O}_{3}\right)$

At low temperature, $\mathrm{Ca}_{2} \mathrm{Al}_{2} \mathrm{~B}_{6} \mathrm{O}_{14}$ is the only stable ternary compound in the system. At $950^{\circ} \mathrm{C}$, $\mathrm{Ca}_{2} \mathrm{Al}_{2} \mathrm{~B}_{6} \mathrm{O}_{14}$ is no longer present. $\mathrm{CaAl}_{2} \mathrm{~B}_{2} \mathrm{O}_{7}$ and $\mathrm{Ca}_{2} \mathrm{Al}_{2} \mathrm{~B}_{2} \mathrm{O}_{8}$ are stable and the calculated diagram is in agreement with the experimental work of Schäfer \& Kuzel [11] in the lime rich part. The only difference is the $\mathrm{CaB}_{2} \mathrm{O}_{4}-\mathrm{Al}_{4} \mathrm{~B}_{2} \mathrm{O}_{9}$ equilibrium which is observed experimentally but could not be reproduced in the calculation.

The origin of this occurrence / decomposition behavior of the three ternary phases lies in their large difference in entropy. As can easily be seen from data in Table $4, \mathrm{CaAl}_{2} \mathrm{~B}_{2} \mathrm{O}_{7}$ and $\mathrm{Ca}_{2} \mathrm{Al}_{2} \mathrm{~B}_{2} \mathrm{O}_{8}$ have largely positive entropies of formation with respect to the simple oxides. These two ternary compound are entropy stabilized and their Gibbs energy becomes more negative with temperature. In the case of $\mathrm{Ca}_{2} \mathrm{Al}_{2} \mathrm{~B}_{6} \mathrm{O}_{14}$, the calculated standard entropy is formation with respect to the simple oxides is negative, i.e. the Gibbs energy becomes less negative with temperature. One can calculate the decomposition/formation temperatures for the three compounds: $461^{\circ} \mathrm{C}$ for $\mathrm{CaAl}_{2} \mathrm{~B}_{2} \mathrm{O}_{7}, 495^{\circ} \mathrm{C}$ for $\mathrm{Ca}_{2} \mathrm{Al}_{2} \mathrm{~B}_{2} \mathrm{O}_{8}$ and $609^{\circ} \mathrm{C}$ for $\mathrm{Ca}_{2} \mathrm{Al}_{2} \mathrm{~B}_{6} \mathrm{O}_{14}$. Due to the uncertainty in the heat capacity at higher temperature, these values are only indicative and must be confirmed by additional experiments.

Kadiyski et al [16] suspected $\mathrm{Ca}_{2} \mathrm{Al}_{2} \mathrm{~B}_{6} \mathrm{O}_{14}$ to be a high pressure phase. This seems not to be the case as our calculations indicate that it is the stable compound at room temperature. However, the experimental verification of the phase stability may be difficult to obtain in a reasonable amout of time due to the sluggish formation kinetics at low temperature.

\section{Experimental phase equilibria}

The mineralogical composition of all samples are presented in Table 6. The observed weight loss during the thermal treatments is small (below 0.3\%) indicating that boron evaporation is negligible. Based on this data, partial isothermal sections (lime rich part) of the $\mathrm{CaO}-\mathrm{Al}_{2} \mathrm{O}_{3}-\mathrm{B}_{2} \mathrm{O}_{3}$ ternary system were constructed at $950^{\circ} \mathrm{C}$ (Fig. 8) and $1020^{\circ} \mathrm{C}$ (Fig.9). The equilibria presented here agree with the work from Schäfer and Kuzel [11]. Only the two known ternary compounds $\mathrm{CaAl}_{2} \mathrm{~B}_{2} \mathrm{O}_{7}$ and $\mathrm{Ca}_{2} \mathrm{Al}_{2} \mathrm{~B}_{2} \mathrm{O}_{8}$ were detected in agreement with the calculated diagram in Fig. 7. The third reported ternary compound, $\mathrm{Ca}_{2} \mathrm{Al}_{2} \mathrm{~B}_{6} \mathrm{O}_{14}$ is apparently not stable under our experimental conditions. It is important to mention that in both cases, $\mathrm{Ca}_{12} \mathrm{Al}_{14} \mathrm{O}_{33}$ was detected as equilibrium phase. The thermal treatments were performed in air and the origin of the occurrence may be the moisture content in the air. 
Table 6: Phase composition of samples using X-ray powder diffraction $\left(C=C a O, B=B_{2} O_{3}, A=A l_{2} O_{3}\right)$. Phases in brackets are present as traces only.

\begin{tabular}{|l|l|}
\hline Sample & Identified phases \\
\hline 90CA_10CB & $\mathrm{CaAl}_{2} \mathrm{O}_{4}, \mathrm{Ca}_{3} \mathrm{~B}_{2} \mathrm{O}_{6}, \mathrm{CaAl}_{4} \mathrm{O}_{7}$ \\
\hline 80CA_20CB & $\mathrm{Ca}_{3} \mathrm{~B}_{2} \mathrm{O}_{6}, \mathrm{CaAl}_{4} \mathrm{O}_{7}, \mathrm{Ca}_{2} \mathrm{Al}_{2} \mathrm{~B}_{2} \mathrm{O}_{8}$ \\
\hline 50CA_50CB & $\mathrm{Ca}_{2} \mathrm{Al}_{2} \mathrm{~B}_{2} \mathrm{O}_{8}, \mathrm{CaAl}_{2} \mathrm{~B}_{2} \mathrm{O}_{7}, \mathrm{Ca}_{2} \mathrm{~B}_{2} \mathrm{O}_{5}$ \\
\hline 30CA_70CB & $\mathrm{CaAl}_{2} \mathrm{~B}_{2} \mathrm{O}_{7}, \mathrm{Ca}_{2} \mathrm{~B}_{2} \mathrm{O}_{5}, \mathrm{CaB}_{2} \mathrm{O}_{4}$ \\
\hline 85C3A_15CB & $\mathrm{Ca}_{3} \mathrm{Al}_{2} \mathrm{O}_{6}, \mathrm{Ca}_{12} \mathrm{Al}_{14} \mathrm{O}_{33}, \mathrm{Ca}_{3} \mathrm{~B}_{2} \mathrm{O}_{6}$ \\
\hline 75C3A_25CB & $\mathrm{Ca}_{12} \mathrm{Al}_{14} \mathrm{O}_{33}, \mathrm{Ca}_{3} \mathrm{~B}_{2} \mathrm{O}_{6},\left(\mathrm{Ca}_{3} \mathrm{Al}_{2} \mathrm{O}_{6}\right),\left(\mathrm{CaAl}_{2} \mathrm{O}_{4}\right)$ \\
\hline 68C3A_32CB & $\mathrm{Ca}_{12} \mathrm{Al}_{14} \mathrm{O}_{33}, \mathrm{Ca}_{3} \mathrm{~B}_{2} \mathrm{O}_{6}, \mathrm{CaAl}_{2} \mathrm{O}_{4},\left(\mathrm{CaAl}_{4} \mathrm{O}_{7}\right)$ \\
\hline 60C3A_40CB & $\mathrm{Ca}_{3} \mathrm{~B}_{2} \mathrm{O}_{6}, \mathrm{CaAl}_{4} \mathrm{O}_{7}, \mathrm{Ca}_{2} \mathrm{Al}_{2} \mathrm{~B}_{2} \mathrm{O}_{8},\left(\mathrm{Ca}_{12} \mathrm{Al}_{14} \mathrm{O}_{33}\right)$ \\
\hline 50C3A_50CB & $\mathrm{Ca}_{3} \mathrm{~B}_{2} \mathrm{O}_{6}, \mathrm{Ca}_{2} \mathrm{Al}_{2} \mathrm{~B}_{2} \mathrm{O}_{8}, \mathrm{Ca}_{2} \mathrm{~B}_{2} \mathrm{O}_{5},\left(\mathrm{CaAl}_{4} \mathrm{O}_{7}\right),\left(\mathrm{Ca}_{12} \mathrm{Al}_{14} \mathrm{O}_{33}\right)$ \\
\hline 40C3A_60CB & $\mathrm{Ca}_{2} \mathrm{Al}_{2} \mathrm{~B}_{2} \mathrm{O}_{8}, \mathrm{Ca}_{2} \mathrm{~B}_{2} \mathrm{O}_{5}, \mathrm{CaAl}_{2} \mathrm{~B}_{2} \mathrm{O}_{7}$ \\
\hline 30C3A_70CB & $\mathrm{Ca}_{2} \mathrm{~B}_{2} \mathrm{O}_{5}, \mathrm{CaAl}_{2} \mathrm{~B}_{2} \mathrm{O}_{7}, \mathrm{CaB}_{2} \mathrm{O}_{4}$ \\
\hline Ter_70C_10B_20A & $\mathrm{Ca}_{3} \mathrm{Al}_{2} \mathrm{O}_{6}, \mathrm{Ca}_{3} \mathrm{~B}_{2} \mathrm{O}_{6}, \mathrm{CaO}^{-} \mathrm{CaO}_{2}$ \\
\hline Ter_30C_55B_55A & $\mathrm{CaAl}_{4} \mathrm{O}_{7}, \mathrm{Ca}_{2} \mathrm{Al}_{2} \mathrm{~B}_{2} \mathrm{O}_{8}, \mathrm{CaAl}_{12} \mathrm{O}_{19}$ \\
\hline Ter_25C_25B_50A & $\mathrm{Ca}_{2} \mathrm{Al}_{2} \mathrm{~B}_{2} \mathrm{O}_{8}, \mathrm{CaAl}_{2} \mathrm{~B}_{2} \mathrm{O}_{7}, \mathrm{Al}_{2} \mathrm{O}_{3}$ \\
\hline
\end{tabular}




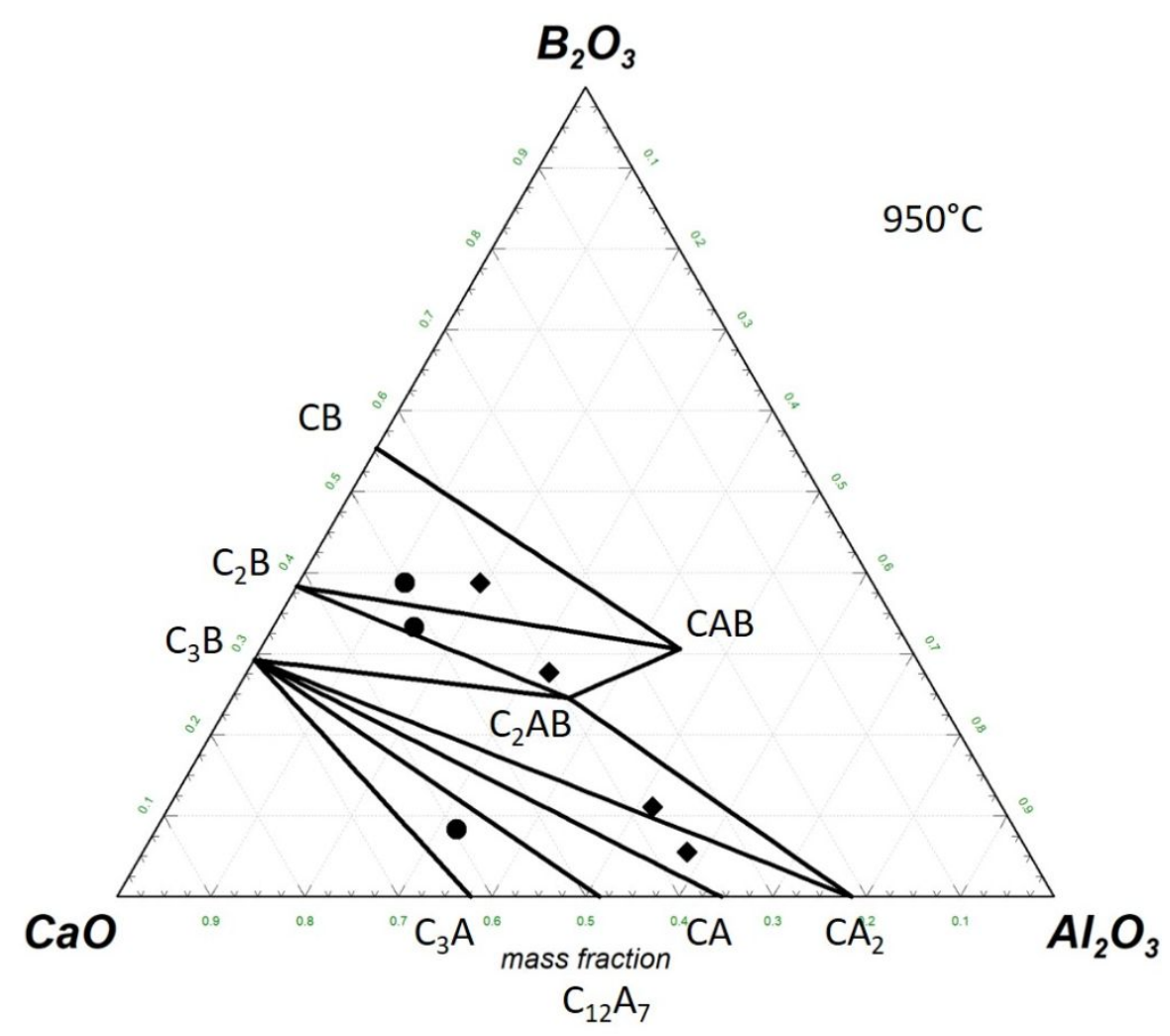

Fig.8: Partial isothermal section of the CaO-rich corner of the $\mathrm{CaO}-\mathrm{Al}_{2} \mathrm{O}_{3}-\mathrm{B}_{2} \mathrm{O}_{3}$ system at $950^{\circ} \mathrm{C}$ with experimental points $\left(\mathrm{C}=\mathrm{CaO}, \mathrm{A}=\mathrm{Al}_{2} \mathrm{O}_{3}, \mathrm{~B}=\mathrm{B}_{2} \mathrm{O}_{3}\right)$ 


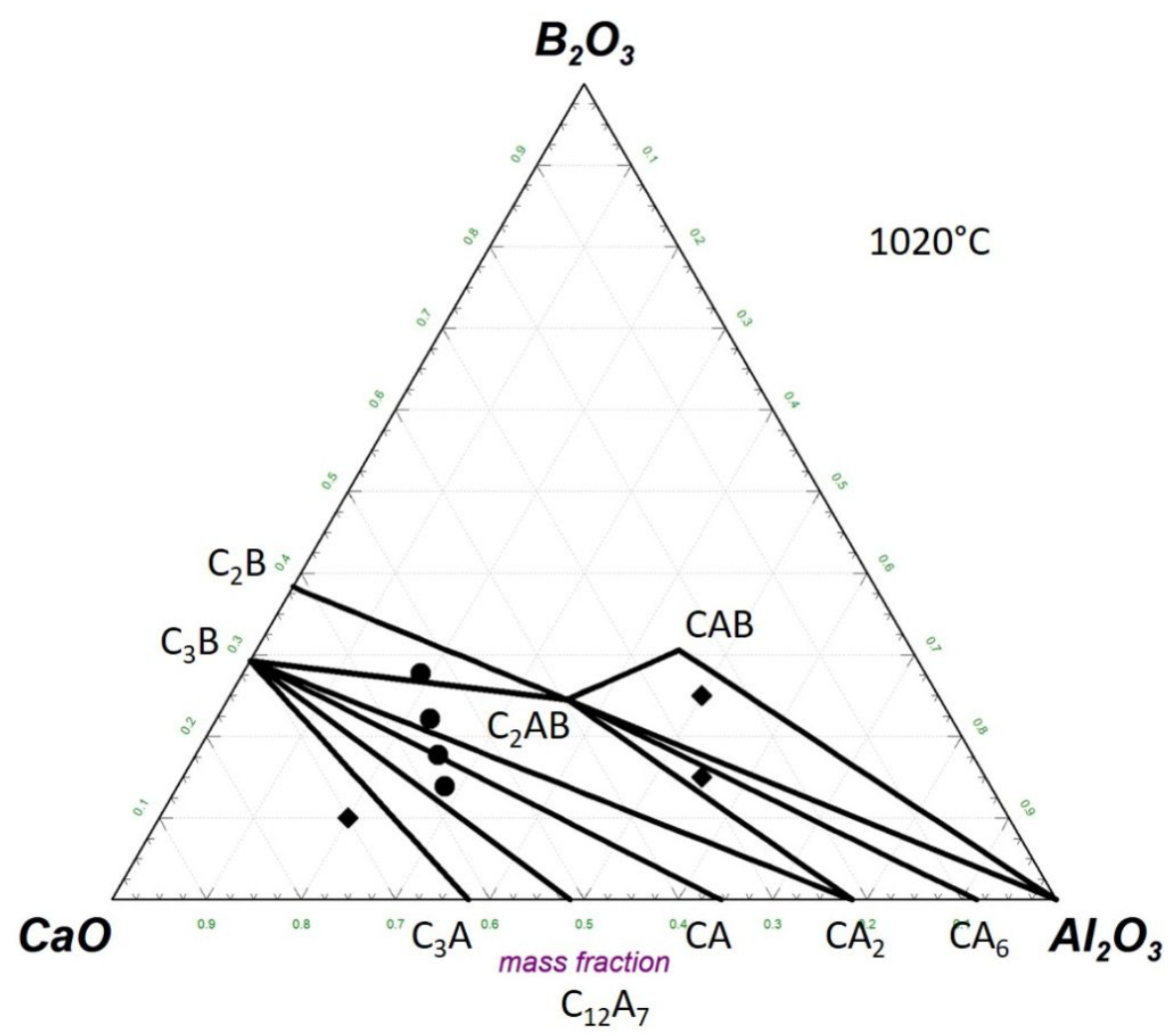

Fig.9: Partial isothermal section of the CaO-rich corner of the $\mathrm{CaO}-\mathrm{Al}_{2} \mathrm{O}_{3}-\mathrm{B}_{2} \mathrm{O}_{3}$ system at $1020^{\circ} \mathrm{C}$ with experimental points $\left(\mathrm{C}=\mathrm{CaO}, \mathrm{A}=\mathrm{Al}_{2} \mathrm{O}_{3}, \mathrm{~B}=\mathrm{B}_{2} \mathrm{O}_{3}\right)$

The heat effects recorded during the DSC measurements could only be evaluated on the first heating cycle. Considerable undercooling is observed especially in the boron rich samples. Therefore, only the measured temperatures of the first heating step are reported here. The observed temperatures of the invariant reactions and the liquidus are summed up in Table 7 together with the observed weight loss in the DSC measurements. Based on these observed temperatures, tentative $\mathrm{T}-\mathrm{x}$ sections were drawn including the experimental data points of the heat effects (Fig. $10 \& 11$ ). Only the solid-solid equilibria and the measured invariants were drawn. It would have been speculative to add liquidus lines with the few available experimental data points in the boron rich part of the diagrams. The weight loss after the DSC experiment (complete fusion of the sample at high temperature) in all samples is small (less than 1.2\%) which indicates that the boron evaporation for the complete measuring cycle is also small. Based on the measurements, the corresponding invariant reactions were tentatively derived and are summed 
up in Table 8. If different measured temperatures exist for the same invariant, a mean temperature was calculated from the individual data points. A tentative liquids surface was also constructed and is presented Fig. 12. It is important to mention, that the liquidus surface is only schematic with arbitrary units for composition. It is not possible to derive the exact compositions for liquid phase from our measurements alone. Further work is needed to determine the exact shape and compositions for the liquidus relations.

Table 7: Recorded temperatures of the measured heat effects and observed weight loss during DSC experiments

\begin{tabular}{|l|c|c|c|c|c|}
\hline sample & $\begin{array}{c}\text { In/mono } \\
\text { variant 1 } \\
{\left[{ }^{\circ} \mathrm{C}\right]}\end{array}$ & $\begin{array}{c}\text { In/mono } \\
\text { variant 2 } \\
{\left[{ }^{\circ} \mathrm{C}\right]}\end{array}$ & $\begin{array}{c}\text { In/mono } \\
\text { variant 3 } \\
{\left[{ }^{\circ} \mathrm{C}\right]}\end{array}$ & $\begin{array}{c}\text { Liquidus } \\
{\left[{ }^{\circ} \mathrm{C}\right]}\end{array}$ & $\begin{array}{c}\text { Observed } \\
\text { weight } \\
\text { loss [\%] }\end{array}$ \\
\hline 90CA_10CB & 1241 & & & & 0.9 \\
\hline 80CA_20CB & 1074 & 1237 & & & 1.0 \\
\hline 50CA_50CB & 986 & & & 1095 & 1.1 \\
\hline 30CA_70CB & 950 & & & 1068 & 1.2 \\
\hline 85C3A_15CB & 1257 & 1287 & & & 0.9 \\
\hline 75C3A_25CB & 1255 & 1278 & 1310 & 1322 & 0.9 \\
\hline 60C3A_40CB & 1078 & 1226 & & 1253 & 1.2 \\
\hline 50C3A_50CB & 1085 & & & 1165 & 1.2 \\
\hline 40C3A_60CB & 984 & 1051 & & 1181 & 1.1 \\
\hline 30C3A_70CB & 950 & & & 1370 & 0.8 \\
\hline Ter_70C_10B_20A & 1285 & 133 & & & 1.1 \\
\hline Ter_30C_15B_55A & 1090 & & & & 0.2 \\
\hline Ter_25C_25B_50A & 1017 & 1073 & & & 1.0 \\
\hline C2AB (CaAlBO 4 ) & 1093 & & & & 1.1 \\
\hline CAB (CaAl $\mathrm{B}_{2} \mathrm{O}_{7}$ ) & 1053 & & & 1240 & 0.6 \\
\hline
\end{tabular}




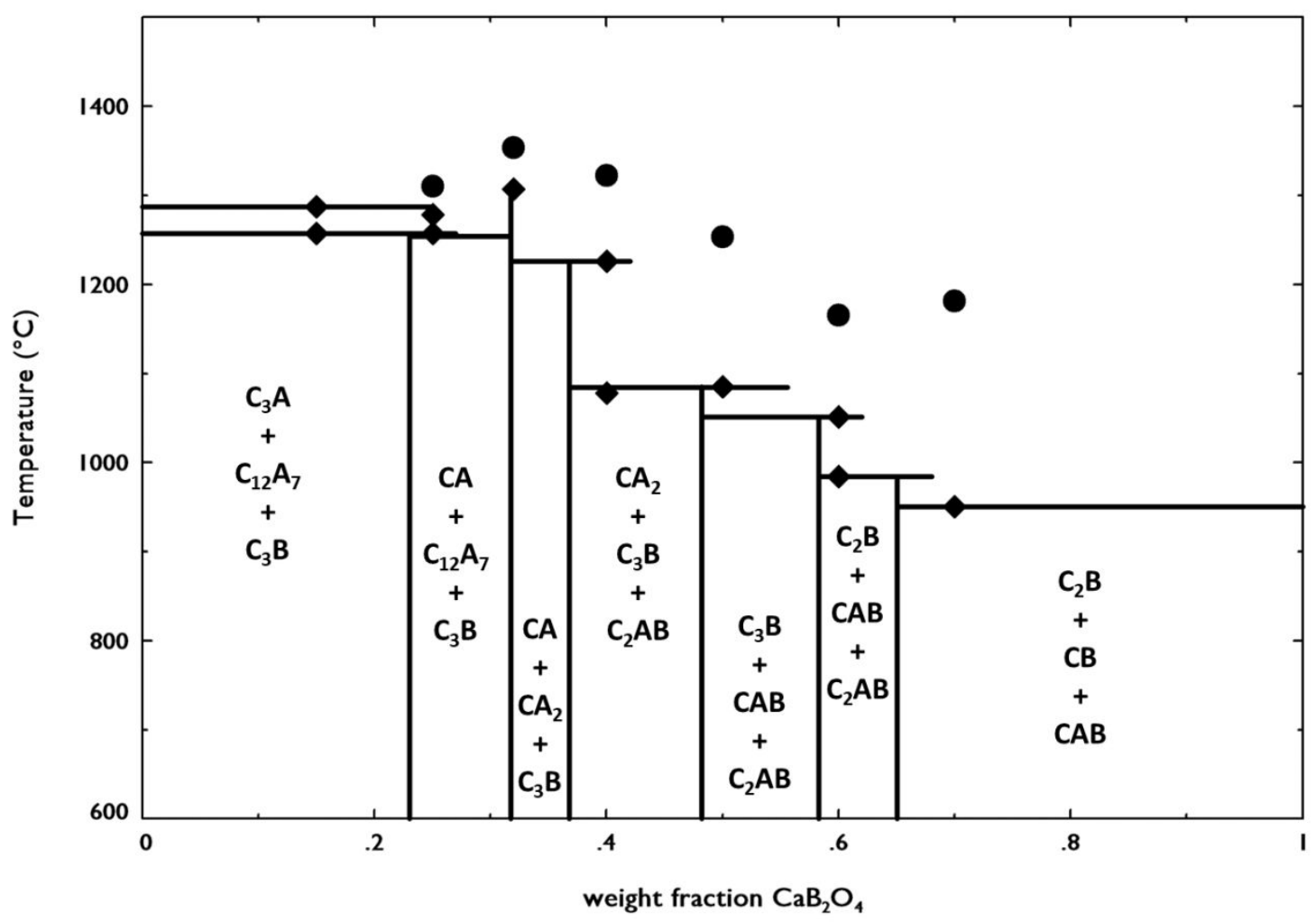

Fig. 10: $\mathrm{Ca}_{3} \mathrm{Al}_{2} \mathrm{O}_{6}-\mathrm{CaB}_{2} \mathrm{O}_{4} \mathrm{~T}-\mathrm{x}$ section with experimental points ( $\mathrm{x}=$ weight fraction, $\mathrm{C}=\mathrm{CaO}, \mathrm{A}=\mathrm{Al}_{2} \mathrm{O}_{3}$, $\left.\mathrm{B}=\mathrm{B}_{2} \mathrm{O}_{3}\right)$ 


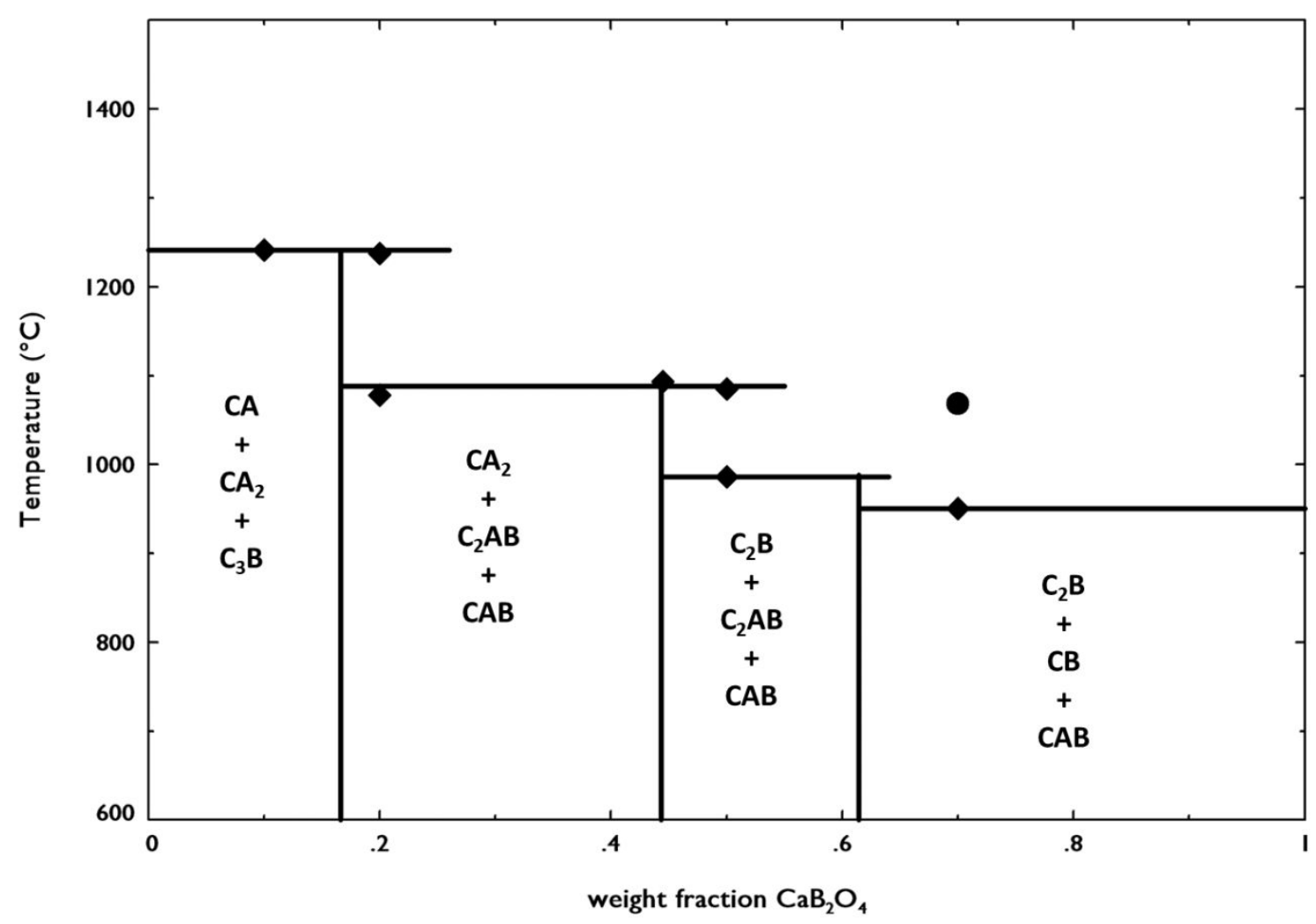

Fig. 11: $\mathrm{CaAl}_{2} \mathrm{O}_{4}-\mathrm{CaB}_{2} \mathrm{O}_{4} \mathrm{~T}$-x section with experimental points ( $\mathrm{x}=$ weight fraction ; $\mathrm{C}=\mathrm{CaO}, \mathrm{A}=\mathrm{Al}_{2} \mathrm{O}_{3}$, $\left.\mathrm{B}=\mathrm{B}_{2} \mathrm{O}_{3}\right)$ 


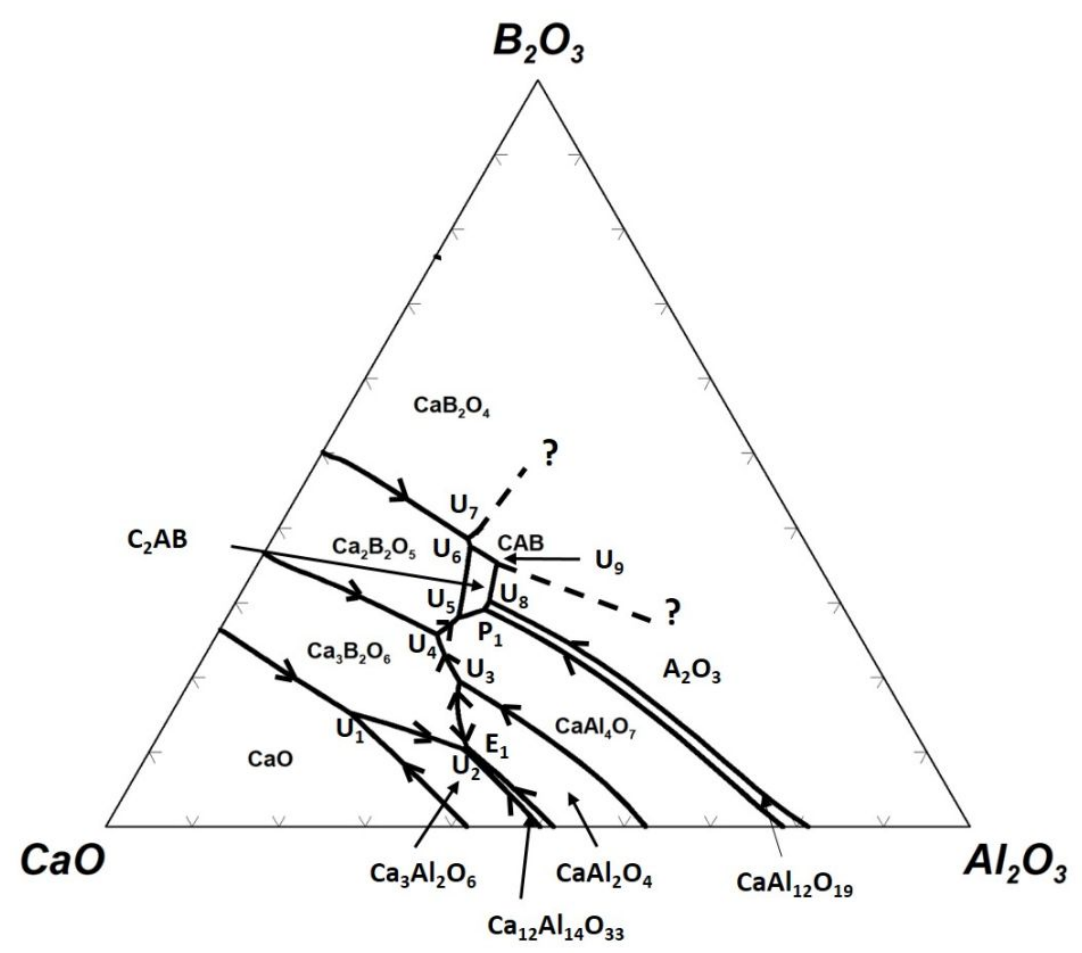

Fig.12: Tentative liquids surface (arbitrary units) of the CaO-rich corner of the $\mathrm{CaO}-\mathrm{Al}_{2} \mathrm{O}_{3}-\mathrm{B}_{2} \mathrm{O}_{3}$ system based on the results of the phase analyses and the DSC measurements.

Table 8: Tentative invariant reactions in the CaO-rich corner of the $\mathrm{CaO}-\mathrm{Al}_{2} \mathrm{O}_{3}-\mathrm{B}_{2} \mathrm{O}_{3}$ system based on the results of the DSC measurements. The experimental uncertainties are estimated to $\pm 5 \mathrm{~K}$

\begin{tabular}{|l|c|c|}
\hline Reaction & Type & $\begin{array}{c}\text { Temperature } \\
{\left[{ }^{\circ} \mathrm{C}\right.}\end{array}$ \\
\hline $\mathrm{Ca}_{3} \mathrm{Al}_{2} \mathrm{O}_{6}+\mathrm{Ca}_{3} \mathrm{~B}_{2} \mathrm{O}_{6}=\mathrm{CaO}+\mathrm{Liq}$ & $\mathrm{U}_{1}$ & 1330 \\
\hline $\mathrm{Ca}_{12} \mathrm{Al}_{14} \mathrm{O}_{33}+\mathrm{Ca}_{3} \mathrm{~B}_{2} \mathrm{O}_{6}=\mathrm{Ca}_{3} \mathrm{Al}_{2} \mathrm{O}_{6}+\mathrm{Liq}$ & $\mathrm{U}_{2}$ & 1257 \\
\hline $\mathrm{Ca}_{12} \mathrm{Al}_{14} \mathrm{O}_{33}+\mathrm{Ca}_{3} \mathrm{~B}_{2} \mathrm{O}_{6}+\mathrm{CaAl}_{2} \mathrm{O}_{4}=\mathrm{Liq}$ & $\mathrm{E}_{1}$ & 1255 \\
\hline $\mathrm{CaAl}_{4} \mathrm{O}_{7}+\mathrm{Ca}_{3} \mathrm{~B}_{2} \mathrm{O}_{5}=\mathrm{CaAl}_{2} \mathrm{O}_{4}+\mathrm{Liq}$ & $\mathrm{U}_{3}$ & 1241 \\
\hline $\mathrm{CaAl}_{4} \mathrm{O}_{7}+\mathrm{Ca}_{2} \mathrm{~B}_{2} \mathrm{O}_{5}=\mathrm{Ca}_{3} \mathrm{~B}_{2} \mathrm{O}_{6}+\mathrm{Liq}$ & $\mathrm{U}_{4}$ & 1076 \\
\hline $\mathrm{CaAl}_{4} \mathrm{O}_{7}+\mathrm{Ca}_{2} \mathrm{~B}_{2} \mathrm{O}_{5}=\mathrm{Ca}_{2} \mathrm{Al}_{2} \mathrm{~B}_{2} \mathrm{O}_{8}+\mathrm{Liq}$ & $\mathrm{U}_{5}$ & 1051 \\
\hline $\mathrm{CaAl}_{4} \mathrm{O}_{7}+\mathrm{CaAl}_{12} \mathrm{O}_{19}+\mathrm{Liq}=\mathrm{Ca}_{2} \mathrm{Al}_{2} \mathrm{~B}_{2} \mathrm{O}_{8}$ & $\mathrm{P}_{1}$ & 1090 \\
\hline
\end{tabular}




\begin{tabular}{|l|c|c|}
\hline $\mathrm{Ca}_{2} \mathrm{~B}_{2} \mathrm{O}_{5}+\mathrm{CaAl}_{2} \mathrm{~B}_{2} \mathrm{O}_{7}=\mathrm{Ca}_{2} \mathrm{Al}_{2} \mathrm{~B}_{2} \mathrm{O}_{8}+\mathrm{Liq}$ & $\mathrm{U}_{6}$ & 985 \\
\hline $\mathrm{CaAl}_{2} \mathrm{~B}_{2} \mathrm{O}_{7}+\mathrm{CaB}_{2} \mathrm{O}_{4}=\mathrm{Ca}_{2} \mathrm{~B}_{2} \mathrm{O}_{5}+\mathrm{Liq}$ & $\mathrm{U}_{7}$ & 950 \\
\hline $\mathrm{CaAl}_{2} \mathrm{~B}_{2} \mathrm{O}_{7}+\mathrm{Ca}_{2} \mathrm{Al}_{2} \mathrm{~B}_{2} \mathrm{O}_{8}=\mathrm{CaAl}_{12} \mathrm{O}_{19}+\mathrm{Liq}$ & $\mathrm{U}_{8}$ & 1073 \\
\hline $\mathrm{CaAl}_{2} \mathrm{~B}_{2} \mathrm{O}_{7}+\mathrm{Ca}_{2} \mathrm{Al}_{2} \mathrm{~B}_{2} \mathrm{O}_{8}=\mathrm{Al}_{2} \mathrm{O}_{3}+$ Liq & $\mathrm{U}_{9}$ & 1017 \\
\hline
\end{tabular}

The starting point of this paper was to resolve the origin of the differences between the calculated and the experimentally observed diagram by Schäfer and Kuzel [11] and specially to determine the temperatures of the invariant reactions in the lime rich part of the $\mathrm{CaO}-\mathrm{Al}_{2} \mathrm{O}_{3}-\mathrm{B}_{2} \mathrm{O}_{3}$ ternary system. From our measurements, it can now be clearly stated that the thermodynamic modeling and the underlying Gibbs energy data in the FactSage FTOxid database must be wrong. The limerichest invariant involving $\mathrm{CaO}, \mathrm{Ca}_{3} \mathrm{Al}_{2} \mathrm{O}_{6}$ and $\mathrm{Ca}_{3} \mathrm{~B}_{2} \mathrm{O}_{6}$ is a U-type reaction and the observed temperature of $1330^{\circ} \mathrm{C}$ is more than $600 \mathrm{~K}$ higher than the calculated value. The non-congruent melting of the two ternary compounds was confirmed. $\mathrm{Ca}_{2} \mathrm{Al}_{2} \mathrm{~B}_{2} \mathrm{O}_{8}$ decomposes peritectically $\left(\mathrm{P}_{1}\right)$ to a boron richer liquid, $\mathrm{CaAl}_{4} \mathrm{O}_{7}$ and a small amount of $\mathrm{CaAl}_{12} \mathrm{O}_{19}$ at $1090 \pm 5^{\circ} \mathrm{C}$ which is in good agreement with the value from Schäfer and Kuzel $\left(1098 \pm 10^{\circ} \mathrm{C}\right)$. The melting temperature for $\mathrm{CaAl}_{2} \mathrm{~B}_{2} \mathrm{O}_{7}$ of $1053^{\circ} \mathrm{C}$ is $\sim 40 \mathrm{~K}$ higher $\left(1015 \pm 10^{\circ} \mathrm{C}\right)$. The reported temperature from Schäfer and Kuzel is most likely the invariant reaction $U_{9}$ of the two ternary compounds with $\mathrm{Al}_{2} \mathrm{O}_{3}$ at $1017^{\circ} \mathrm{C}$ (first heat effect of sample Ter_25C_50A_25B).

\section{Conclusion}

Partial phase equilibria in the $\mathrm{CaO}-\mathrm{Al}_{2} \mathrm{O}_{3}-\mathrm{B}_{2} \mathrm{O}_{3}$ were investigated theoretically using thermodynamic modeling and experimentally with X-ray diffraction and Differential Scanning Calorimetry.

The thermodynamic properties of the three ternary compounds were calculated using DFT and lattice dynamics theory. $\mathrm{Ca}_{2} \mathrm{Al}_{2} \mathrm{~B}_{6} \mathrm{O}_{14}$ is the only stable ternary compound at low temperature. The two others, $\mathrm{CaAl}_{2} \mathrm{~B}_{2} \mathrm{O}_{7}$ and $\mathrm{Ca}_{2} \mathrm{Al}_{2} \mathrm{~B}_{2} \mathrm{O}_{8}$ form at higher temperature through solid-solid reactions. The calculated entropy of formation of the latter two compounds with respect to $\mathrm{CaO}, \mathrm{Al}_{2} \mathrm{O}_{3}$ and $\mathrm{B}_{2} \mathrm{O}_{3}$ is largely positive which explains this behavior. Both compounds are entropy stabilized and the Gibbs energy of formation becomes more negative with increasing temperature.

Partial experimental isothermal sections were determined at $950^{\circ} \mathrm{C}$ and $1020^{\circ} \mathrm{C}$. The measured data agrees with earlier experimental work in the literature. The lime-rich invariant reaction involving $\mathrm{CaO}, \mathrm{Ca}_{3} \mathrm{Al}_{2} \mathrm{O}_{6}$ and $\mathrm{Ca}_{3} \mathrm{~B}_{2} \mathrm{O}_{6}$ is of $\mathrm{U}$-type with a transformation temperature of $1330^{\circ} \mathrm{C}$ 
instead of the calculated one of $677^{\circ} \mathrm{C}$. Two T-x sections, $\mathrm{Ca}_{3} \mathrm{Al}_{2} \mathrm{O}_{6}-\mathrm{CaB}_{2} \mathrm{O}_{4}$ and $\mathrm{CaAl}_{2} \mathrm{O}_{4}-\mathrm{CaB}_{2} \mathrm{O}_{4}$ were constructed and the corresponding invariant reactions identified. Thermal analysis data could only be used from the first heating step because considerable undercooling was observed during cooling for $\mathrm{B}_{2} \mathrm{O}_{3}$ samples. This was expected due to the glass forming ability of $\mathrm{CaO}-\mathrm{Al}_{2} \mathrm{O}_{3}-$ $\mathrm{B}_{2} \mathrm{O}_{3}$ ternary compositions especially for boron rich compositions. Based on the new experimental results, a tentative partial liquidus surface of the lime rich part of the ternary diagram was constructed and corresponding invariant reactions were proposed. Further experimental work is needed to determine the exact composition of the liquid phase and to confirm the type of the invariant reactions.

\section{Acknowledgement}

The authors acknowledge fruitful discussions within the French research consortium on high temperature thermodynamics GDR 3584 “TherMatHT” (www.thermatht.fr). CIMENT/GRICAD in the frame of the "atosimul" project is acknowledged for computational resources.

\section{Reference}

[1] E.M. Gartner, Industrially interesting approaches to "low-CO2" cements, Cement and Concrete Research 2004, 34, p. 1489-1498.

[2] E.M. Gartner, G. Li, High belite-containing sulfoaluminous clinker, method for the productions and the use thereof for preparing hydraulic binders, Patent WO 2006018569 A3, 2006

[3] M. Ben Haha, F. Winnefeld, A. Pisch, Advances in understanding ye'elimite-rich cements, Cement and Concrete Research. 2019, 123, p. 105778.

[4] H.F.W. Taylor, Cement chemistry, $2^{\text {nd }}$ edition, Thomas Telford Publishing, 1997

[5] J.G. Fletcher, F.P. Glasser, Phase relations in the system $\mathrm{CaO}-\mathrm{B}_{2} \mathrm{O}_{3}-\mathrm{SiO}_{2}$. Journal of materials science 1993, 28, p 2677-2686.

[6] P.L. Higby, R.J. Ginther, I.D. Aggarwal, E.J. Friebele, Glass-formation and thermal properties of low-silica calcium aluminosilicate glasses. J. Non-Cryst. Solids, 1990, 126 (3), p 209-215.

[7] F.T. Wallenberger, R.J. Hicks, A.T. Bierhals, Design of environmentally friendly fiberglass compositions: ternary eutectic $\mathrm{SiO}_{2}-\mathrm{Al}_{2} \mathrm{O}_{3}$ - $\mathrm{CaO}$ compositions, structures and properties. J. NonCryst. Solids 2004, 349, p 377-387.

[8] J.F. MacDowell, Aluminoborate Glass-Ceramics with Low Thermal Expansivity. Journal of the American Ceramic Society, 1990, 73(8), p 2287-2292.

[9] C. Hirayama, Properties of aluminoborate glasses of group II metal oxides: I, glass formation and thermal expansion. Journal of the American Ceramic Society 1961, 44, p 602-606. 
[10] R. El-Hayek, F. Ferey, P. Florian, A. Pisch, D.R. Neuville, Structure and properties of lime alumino-borate glasses, Chemical Geology, 2017, 461, p 75-81

[11] U.-L. Schäfer, H.-J. Kuzel, Kompatibilitätsbeziehungen und ternäre Verbindungen im System CaO- $\mathrm{Al}_{2} \mathrm{O}_{3}-\mathrm{B}_{2} \mathrm{O}_{3}$. Neues Jahrb. Mineral. Monatsh. 1967, p 131-136, in German

[12] W. Schuckmann, Zur Struktur des Calcium-Aluminium-Borates, $\mathrm{CaAl}\left[\mathrm{O}_{7} \mathrm{BO}_{3}\right]$, Neues Jahrb. Miner. Monatsh.,1968, p 80-86, in German

[13] K.S. Chang, D.A. Keszler, $\mathrm{CaAl}_{2}\left(\mathrm{BO}_{3}\right)_{2} \mathrm{O}$ : crystal structure. Materials Research Bulletin 1998, 33, p 299-304.

[14] E. Iwase, N. Saito, Johachidolite: a new mineral, a hydrous fluoborate of sodium, calcium and aluminum. Sci. Pap. Inst. Phys. Chem. Res. (Tokyo), 1942, 39, p 300-304, in Japanese [15] P.B. Moore, T. Araki, Johachidolite, CaAl[B307], a borate with very dense atomic structure. Nature, Phys. Sci., 1972, 240, p 63-65.

[16] M. Kadiyski, T. Armbruster, D. Günther, E. Reusser, A. Peretti, Johachidolite, $\mathrm{CaAl}\left[\mathrm{B}_{3} \mathrm{O}_{7}\right]$, a mineralogical and structural peculiarity. Eur. J. Mineral. 2008, 20, p. 965-073.

[17] N.I. Leonyuk, Structural aspects in crystal growth of anhydrous borates. Journal of crystal growth, 1997, 174, p 301-307.

[18] R.R. Harding, J.G. Francis, C.J.E. Oldershaw, A.H. Rankin, Johachidolite - a new gem. J. Gemm., 1999, 26(5), 324-329.

[19] C.W. Bale, E. Bélisle, P. Chartrand, S.A. Decterov, G. Eriksson, A.E. Gheribi, K. Hack, I.-H. Jung, Y.-B. Kang, J. Melançon, A.D. Pelton, S. Petersen, C. Robelin, J. Sangster, P. Spencer, M.-A. Van Ende, FactSage thermochemical software and databases 2010-2016, Calphad 2016, 54, p 35-53

[20] E.T. Carlson, The System: $\mathrm{CaO}-\mathrm{B}_{2} \mathrm{O}_{3}$, J. Res. Nat. Bur. Stand. 1932, 9, p 825.

[21] S.A. Decterov, V. Swamy, I.-H. Jung, Thermodynamic modeling of the $\mathrm{B}_{2} \mathrm{O}_{3}-\mathrm{SiO}_{2}$ and $\mathrm{B}_{2} \mathrm{O}_{3}-\mathrm{Al}_{2} \mathrm{O}_{3}$ system. International Journal of Materials Research 2007, 98, p 988-994.

[22] D. Mazza, M. Vallino, G. Busca, Mullite-Type Structures in the Systems $\mathrm{Al}_{2} \mathrm{O}_{3}-\mathrm{Me}_{2} \mathrm{O}(\mathrm{Me}=\mathrm{Na}$, $\mathrm{K})$ and $\mathrm{Al}_{2} \mathrm{O}_{3}-\mathrm{B}_{2} \mathrm{O}_{3}$, Journal of the American Ceramic Society, 1992, 75(7), p 1929-1934.

[23] R.W. Nurse, J.H. Welch, A.J. Majumdar, The $\mathrm{CaO}-\mathrm{Al}_{2} \mathrm{O}_{3}$ System in a Moisture-free Atmosphere, Transactions of the British Ceramic Society 1965, 64, p 409-418

[24] D.A. Jerebtsov, G.G. Mikhailov, Phase diagram of $\mathrm{CaO}-\mathrm{Al}_{2} \mathrm{O}_{3}$ system. Ceramics International 2001, 27, p 25-28.

[25] R.W. Nurse, J.H. Welch, A.J. Majumdar, The $12 \mathrm{CaO}^{2} 7 \mathrm{Al}_{2} \mathrm{O}_{3}$ Phase in the $\mathrm{CaO}-\mathrm{Al}_{2} \mathrm{O}_{3}$ system. Transactions of the British Ceramic Society 1965, 64, p 323-332.

[26] A.K. Chatterjee, G.I. Zhmoidin, The Phase Equilibrium Diagram of the System $\mathrm{CaO}-\mathrm{Al}_{2} \mathrm{O}_{3}-\mathrm{CaF}_{2}$, Journal of Material Science 1972, 7, p 93-97 
[27] P. Hohenberg, W. Kohn, Inhomogeneous Electron Gas, Physical Review. 1964, 136, p. B864B871.

[28] W. Kohn, L.J. Sham, Self-Consistent Equations Including Exchange and Correlation Effects, Physical Review. 1965, 140, p. A1133-A1138.

[29] G. Kresse, J. Furthmüller, Efficient iterative schemes for ab initio total-energy calculations using a plane-wave basis set, Physical Review B. 1996, 54, p.11169-11186.

[30] G. Kresse, D. Joubert, From ultrasoft pseudopotentials to the projector augmented-wave method, Physical Review B. 1999, 59, p. 1758-1775.

[31] J. Sun, A. Ruzsinszky, J.P. Perdew, Strongly Constrained and Appropriately Normed Semilocal Density Functional, Physical Review Letters. 2015, 115, p. 036402.

[32] Kitchaev, D.A., Peng, H., Liu, Y., Sun, J., Perdew, J.P., Ceder, G., Energetics of MnO2 polymorphs in density functional theory. Physical Review 2016, B93, p. 045132.

[33] H.J. Monkhorst, J.D. Pack, Special points for Brillouin-zone integrations, Physical Review 1976, B13, p. 5188-5192.

[34] P.E. Blöchl, O. Jepsen, O.K. Andersen, Improved tetrahedron method for Brillouin-zone integrations, Physical Review 1994, B49, p. 16223-16233.

[35] A. Togo, I. Tanaka, First principles phonon calculations in materials science, Scripta Materialia. 2015, 108, p. 1-5. 


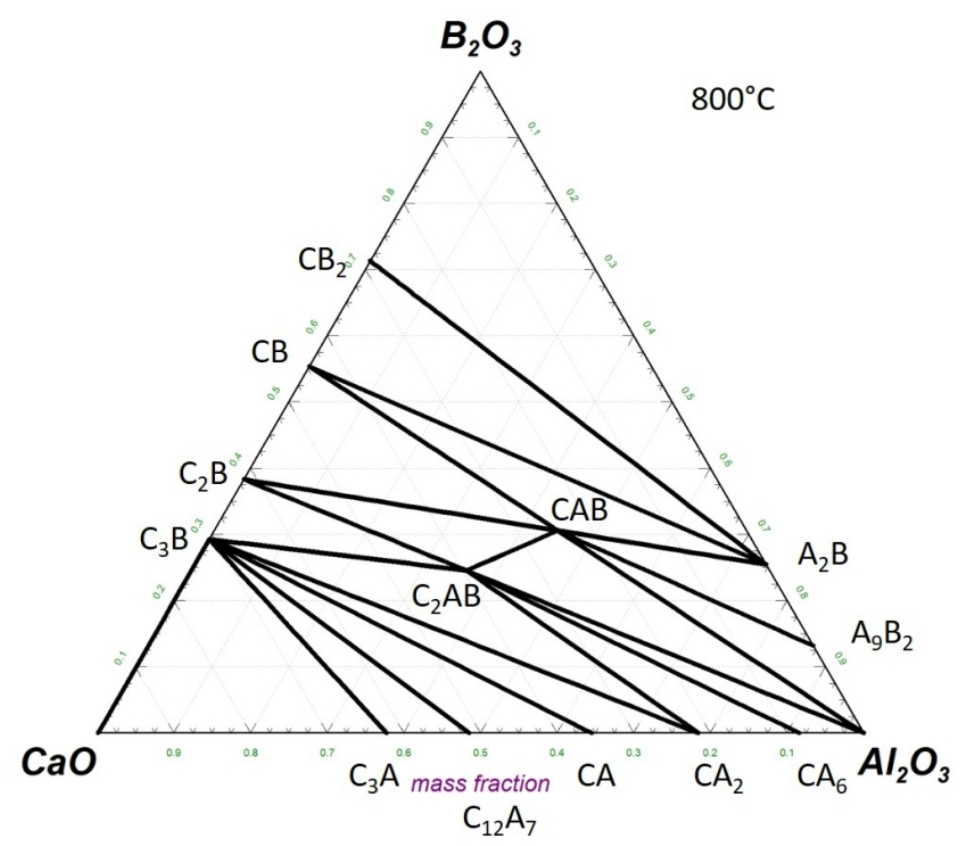

Experimental isothermal section of the $\mathrm{CaO}-\mathrm{Al} 2 \mathrm{O} 3-\mathrm{B} 2 \mathrm{O} 3$ system at $800^{\circ} \mathrm{C}$ reproduced using the data from Schäfer and Kuzel [10]

$235 \times 185 \mathrm{~mm}(150 \times 150 \mathrm{DPI})$ 


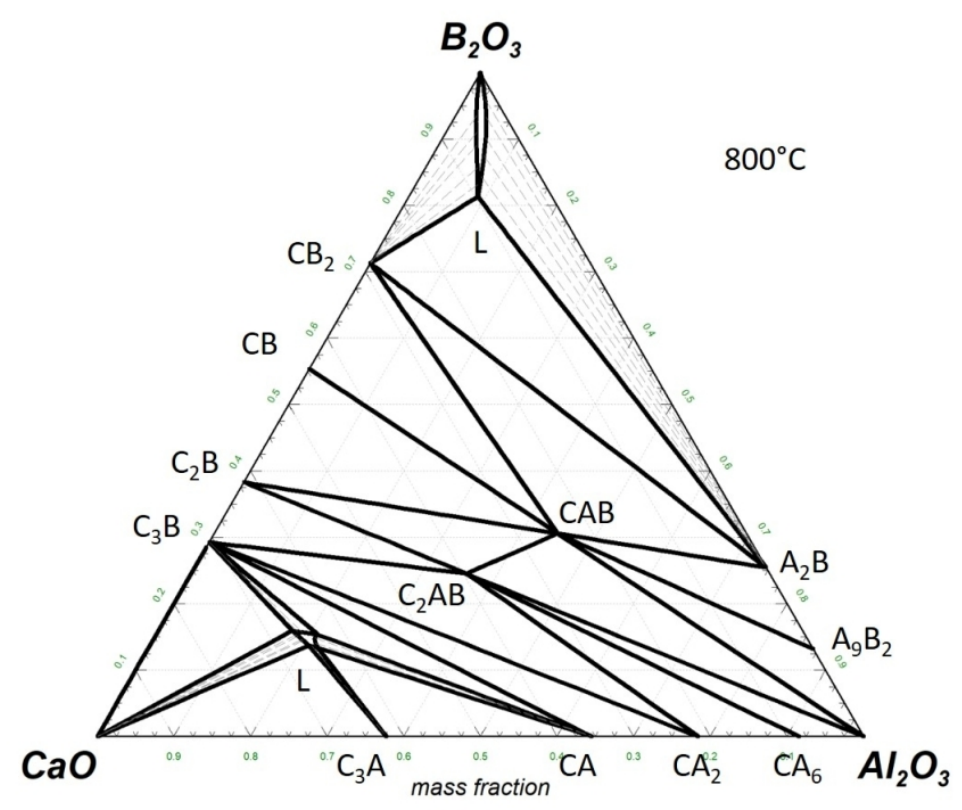

Calculated isothermal section of the $\mathrm{CaO}-\mathrm{Al} 2 \mathrm{O} 3-\mathrm{B} 2 \mathrm{O} 3$ system at $800^{\circ} \mathrm{C}$ using thermodynamic data from the FTOxid database and the FactSage Gibbs energy minimizer (v.7.3) [19]. L corresponds to the liquid phase ; compounds in reduced notation $\mathrm{C}=\mathrm{CaO}, \mathrm{A}=\mathrm{Al} 2 \mathrm{O} 3, \mathrm{~B}=\mathrm{B} 2 \mathrm{O} 3$.

$241 \times 190 \mathrm{~mm}(150 \times 150 \mathrm{DPI})$ 


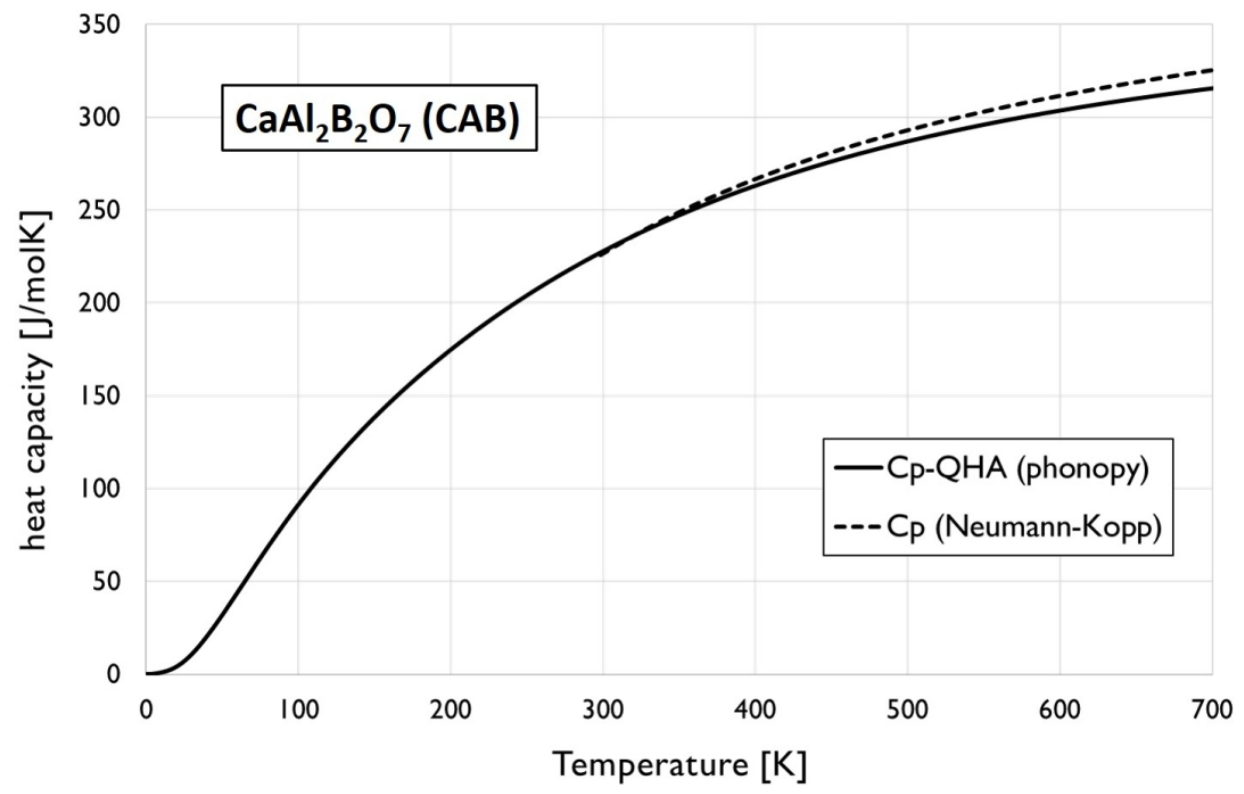

Calculated heat capacity at constant pressure in the quasi-harmonic approximation for CaAl2B2O7 (full line) as compared to Neumann-Kopp's additive rule (dotted line) using data from the Factsage pure substance database for $\mathrm{CaO}, \mathrm{Al} 2 \mathrm{O} 3$ and $\mathrm{B} 2 \mathrm{O} 3$.

\section{$257 \times 168 \mathrm{~mm}(150 \times 150 \mathrm{DPI})$}




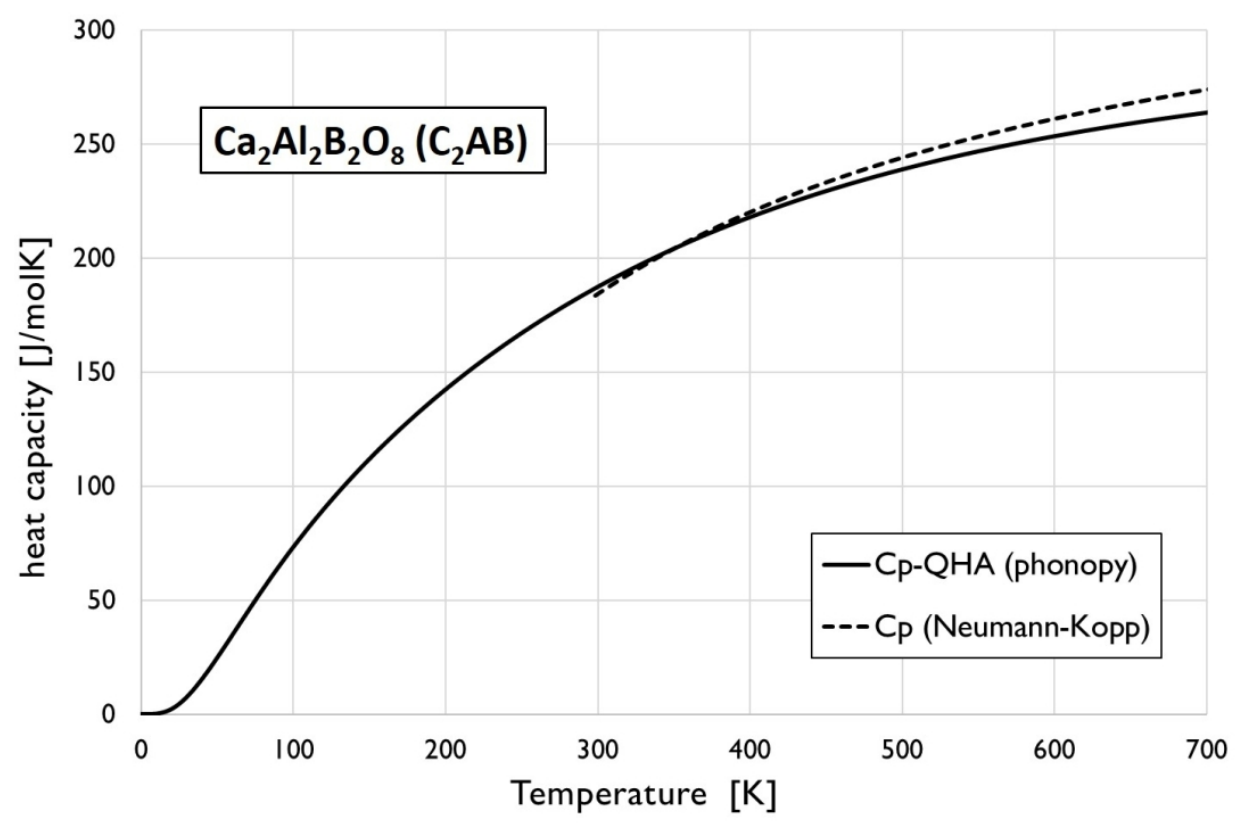

Calculated heat capacity at constant pressure in the quasi-harmonic approximation for Ca2Al2B2O8 (full line) as compared to Neumann-Kopp's additive rule (dotted line) using data from the Factsage pure substance database for $\mathrm{CaO}, \mathrm{Al} 2 \mathrm{O} 3$ and $\mathrm{B} 2 \mathrm{O} 3$.

$257 \times 167 \mathrm{~mm}(150 \times 150 \mathrm{DPI})$ 


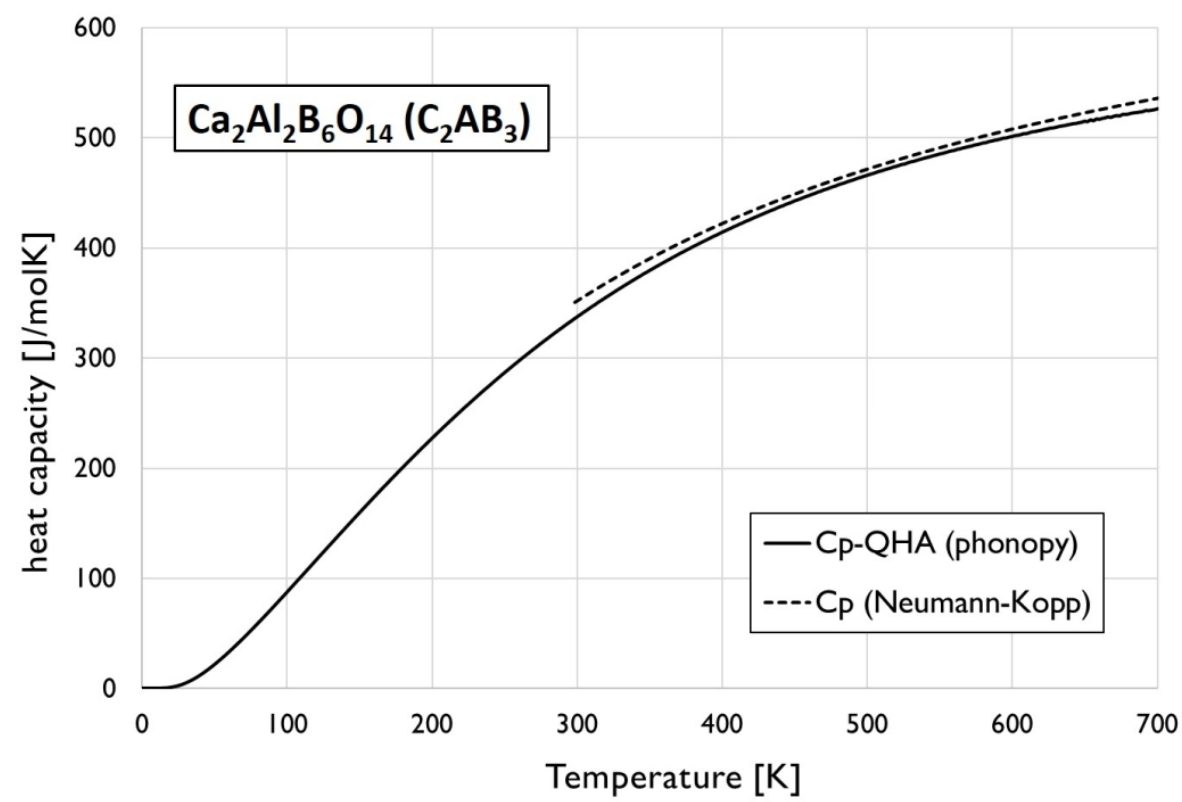

Calculated heat capacity at constant pressure in the quasi-harmonic approximation for Ca2Al2B6O14 (full line) as compared to Neumann-Kopp's additive rule (dotted line) using data from the Factsage pure substance database for $\mathrm{CaO}, \mathrm{Al} 2 \mathrm{O} 3$ and $\mathrm{B} 2 \mathrm{O} 3$.

$257 \times 167 \mathrm{~mm}(150 \times 150 \mathrm{DPI})$ 


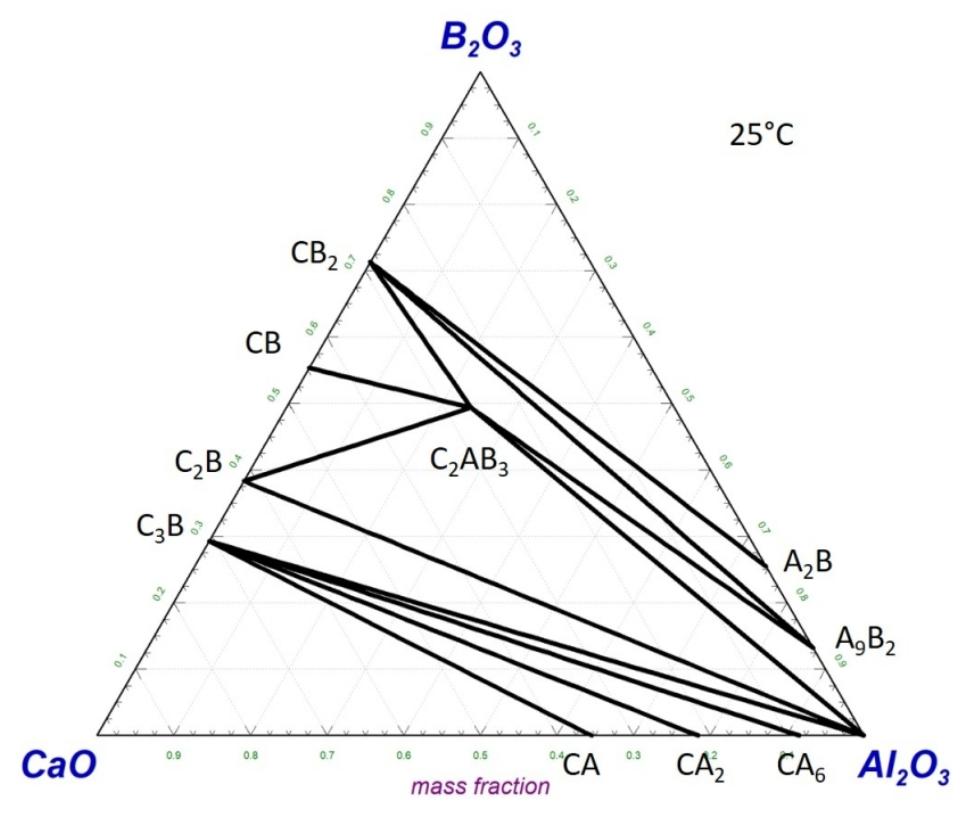

Calculated isothermal section of the $\mathrm{CaO}-\mathrm{Al} 2 \mathrm{O} 3-\mathrm{B} 2 \mathrm{O} 3$ system at $25^{\circ} \mathrm{C}(\mathrm{C}=\mathrm{CaO}, \mathrm{A}=\mathrm{Al} 2 \mathrm{O} 3, \mathrm{~B}=\mathrm{B} 2 \mathrm{O} 3)$ $241 \times 190 \mathrm{~mm}$ ( $150 \times 150$ DPI) 


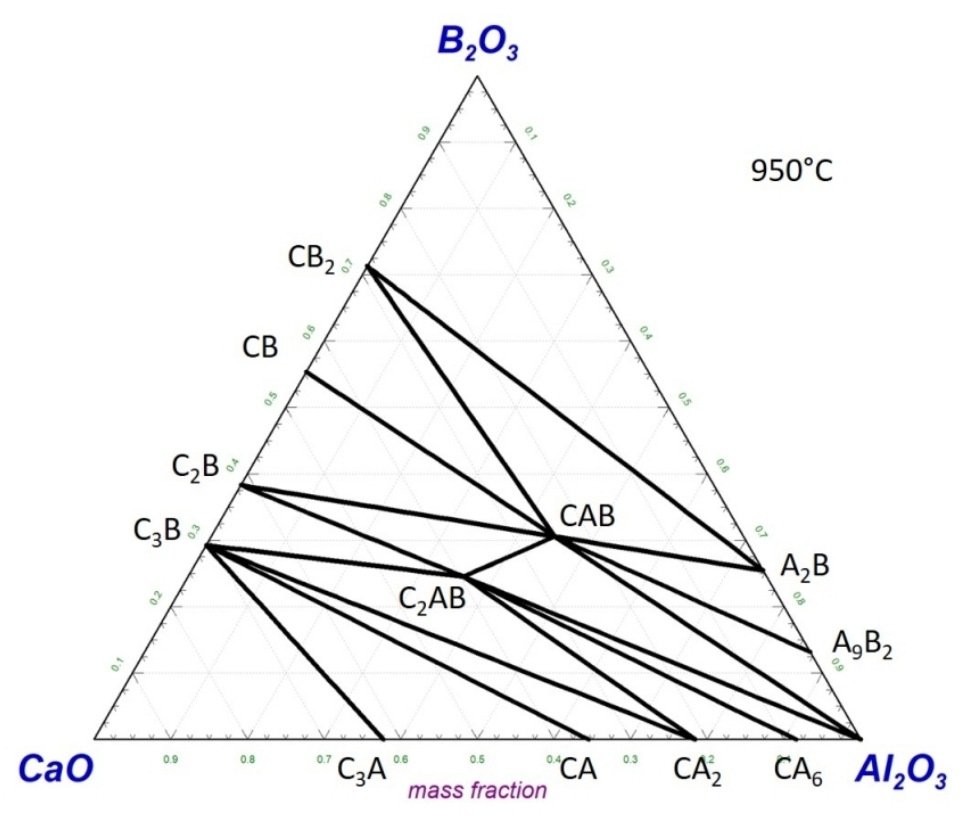

Calculated isothermal section of the $\mathrm{CaO}-\mathrm{Al} 2 \mathrm{O} 3-\mathrm{B} 2 \mathrm{O} 3$ system at $950^{\circ} \mathrm{C}(\mathrm{C}=\mathrm{CaO}, \mathrm{A}=\mathrm{Al} 2 \mathrm{O} 3, \mathrm{~B}=\mathrm{B} 2 \mathrm{O} 3)$

$241 \times 190 \mathrm{~mm}$ (150 x 150 DPI) 


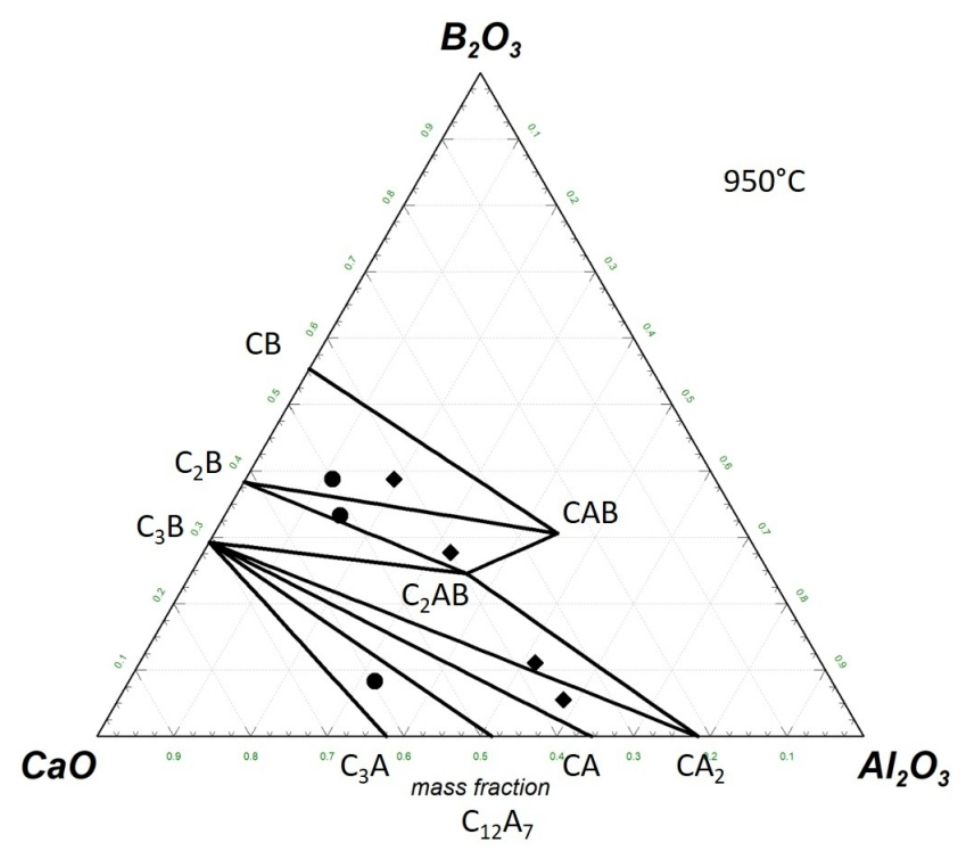

Partial isothermal section of the $\mathrm{CaO}$-rich corner of the $\mathrm{CaO}-\mathrm{Al} 2 \mathrm{O} 3-\mathrm{B} 2 \mathrm{O} 3$ system at $950^{\circ} \mathrm{C}$ with experimental points $(\mathrm{C}=\mathrm{CaO}, \mathrm{A}=\mathrm{Al} 2 \mathrm{O} 3, \mathrm{~B}=\mathrm{B} 2 \mathrm{O} 3)$

$241 \times 190 \mathrm{~mm}(150 \times 150 \mathrm{DPI})$ 
Partial isothermal section of the $\mathrm{CaO}$-rich corner of the $\mathrm{CaO}-\mathrm{Al} 2 \mathrm{O} 3-\mathrm{B} 2 \mathrm{O} 3$ system at $1020^{\circ} \mathrm{C}$ with experimental points $(\mathrm{C}=\mathrm{CaO}, \mathrm{A}=\mathrm{Al} 2 \mathrm{O} 3, \mathrm{~B}=\mathrm{B} 2 \mathrm{O} 3)$

\section{$241 \times 190 \mathrm{~mm}(150 \times 150$ DPI $)$}




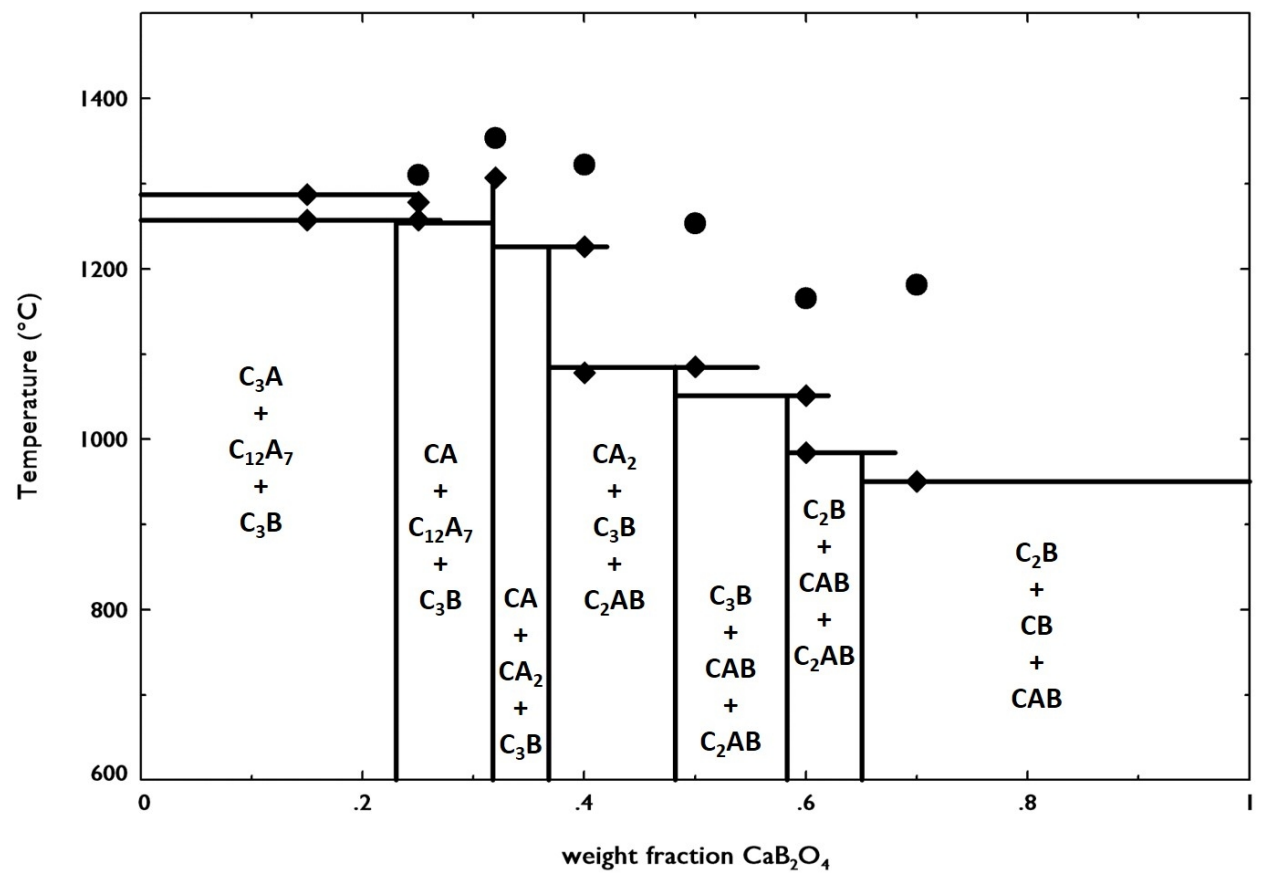

Ca3Al206-CaB2O4 T-x section with experimental points ( $x=$ weight fraction, $C=C a O, A=A l 2 O 3, B=B 2 O 3$ )

$241 \times 190 \mathrm{~mm}(150 \times 150 \mathrm{DPI})$ 


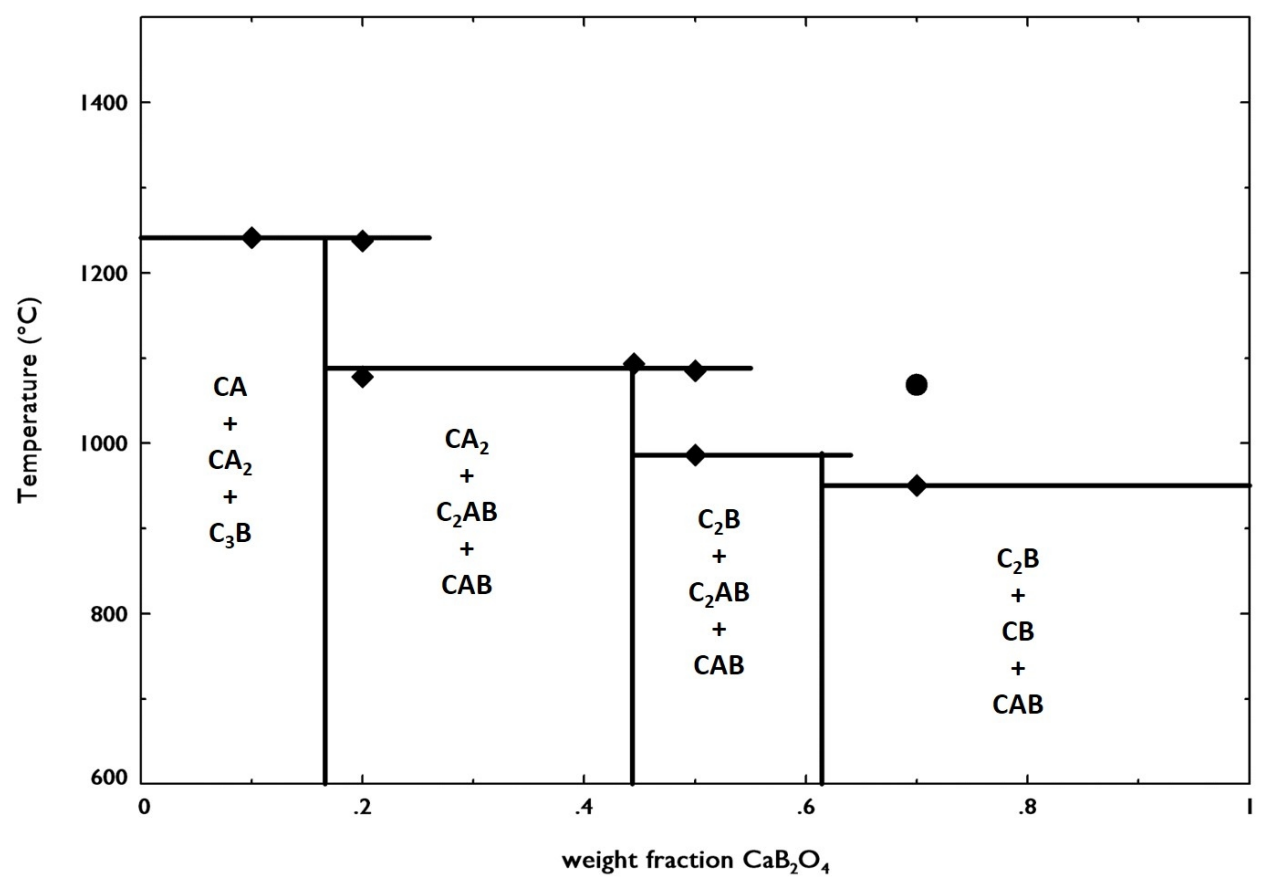

CaAl2O4-CaB2O4 T-x section with experimental points ( $\mathrm{x}=$ weight fraction ; $\mathrm{C}=\mathrm{CaO}, \mathrm{A}=\mathrm{Al} 2 \mathrm{O} 3, \mathrm{~B}=\mathrm{B} 2 \mathrm{O} 3$ )

$241 \times 190 \mathrm{~mm}(150 \times 150 \mathrm{DPI})$ 


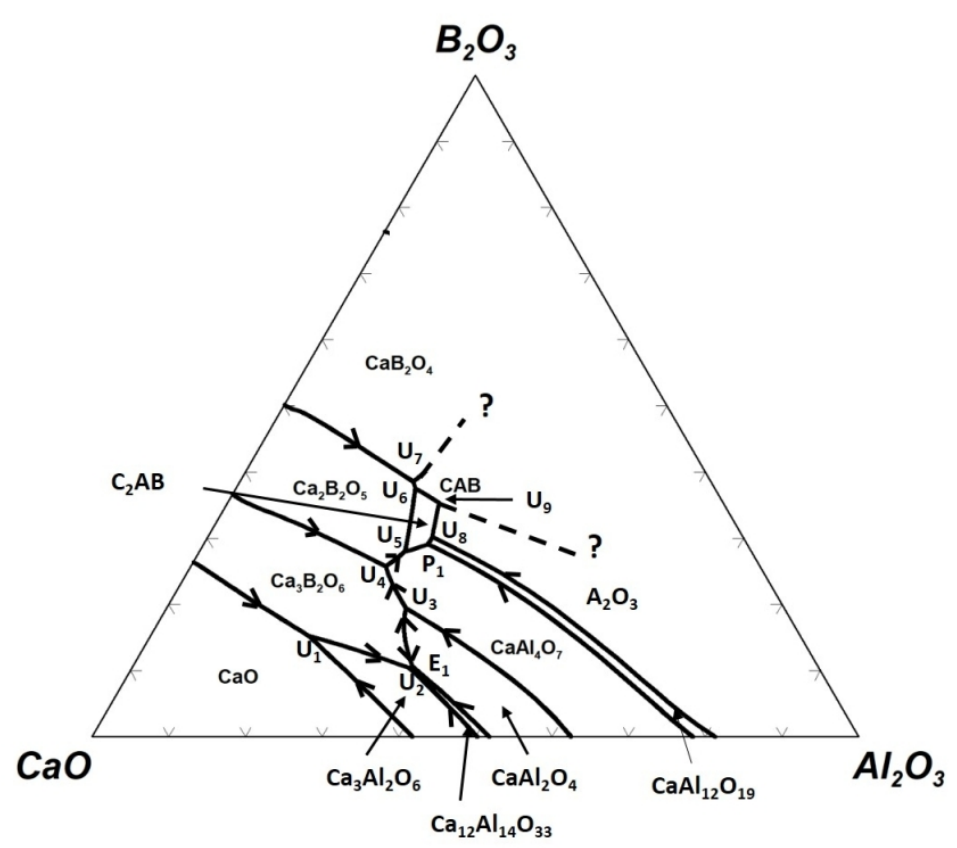

Tentative liquids surface (arbitrary units) of the $\mathrm{CaO}-$ rich corner of the $\mathrm{CaO}-\mathrm{Al} 2 \mathrm{O} 3-\mathrm{B} 2 \mathrm{O} 3$ system based on the results of the phase analyses and the DSC measurements.

$241 \times 190 \mathrm{~mm}(150 \times 150 \mathrm{DPI})$ 